PEDRO AUGUSTO DO AMARAL ABUJAMRA ASSEIS

ReorganizaÇões Societárias InTERnaCiOnais SOB A PERSPECTIVA doS ACORdos Para Evitar a DUPla TributaÇão

\author{
Dissertação de Mestrado \\ Prof. Associado Dr. Gerd Willi Rothmann
}

Universidade de São PaUlo

FACULDADE DE DIREITO

São Paulo - SP

2016 

PEDRO AUGUSTO DO AMARAL ABUJAMRA ASSEIS

\section{ReorganizaÇões Societárias Internacionais sob a Perspectiva dos ACORdos Para Evitar a DUPLA TributaÇÃo}

Dissertação de Mestrado apresentada à Banca Examinadora do Programa de Pós-Graduação em Direito, da Faculdade de Direito da Universidade de São Paulo, como exigência parcial para obtenção do título de Mestre em Direito, na área de Concentração de Direito Econômico, Financeiro e Tributário, sob a orientação do Professor Associado Dr. Gerd Willi Rothmann.

\section{UNIVERSIDAde De SÃo PAUlo \\ FACUldade De Direito}

São Paulo - SP 
Catalogação da Publicação

Serviço de Biblioteca e Documentação

Faculdade de Direito da Universidade de São Paulo

A844r. ASSEIS, Pedro Augusto do Amaral Abujamra

Reorganizações Societárias Internacionais sob a Perspectiva dos Acordos para Evitar a Dupla Tributação / Pedro Augusto do Amaral Abujamra Asseis - Orientador: Gerd Willi Rothmann - São Paulo: 2016.

$102 \mathrm{f}$; $\mathrm{cm}$.

Dissertação (Mestrado - Programa de Pós-Graduação em Direito. Direito Econômico, Financeiro e Tributário) Faculdade de Direito, Universidade de São Paulo, 2016.

1. Direito Tributário. 2. Investimentos Crossborder. 3. Reorganizações Societárias. 4. Acordos para Evitar a Dupla Tributação em Matéria de Imposto de Renda. 5. Direito Internacional Público. I. Rothmann, Gerd Willi, orientador. II. Faculdade de Direito da Universidade de São Paulo. III. Título. 


\section{TERMO DE APROVAÇÃ O}

Nome: ASSEIS, PEDRO AUGUSTO DO AMARAL ABUJAMRA

Título: Reorganizações Societárias Internacionais sob a Perspectiva dos Acordos para Evitar a Dupla Tributação

Dissertação de Mestrado apresentada à Banca Examinadora do Programa de Pós-Graduação em Direito, da Faculdade de Direito da Universidade de São Paulo, como exigência parcial para obtenção do título de Mestre em Direito, na área de Concentração de Direito Econômico, Financeiro e Tributário, sob a orientação do Professor Associado Dr. Gerd Willi Rothmann.

Data de Aprovação: / 2017

B A N C A E X A M I N A D O R A

Prof. Associado Dr. Gerd Willi RothMAnN Julgamento:

Prof. Dr. Julgamento:

Prof. Dr. Julgamento:
Instituição: Universidade de São Paulo (USP)

Assinatura:

Instituição:

Assinatura:

Instituição:

Assinatura: 

À minha família 



\section{AgradeCIMENTOS}

Ao Professor GeRd WiLli Rothmann, não somente por ter-me generosamente aberto as portas da Pós-Graduação - ainda recém-formado - e ser o maior responsável pelo desenvolvimento deste trabalho, mas sobretudo por ter me apresentado ao Direito Tributário Internacional. Sem sua orientação, maestria e didática ímpar, nada disso teria sido possível.

Ao Professor Luís EdUARDo SCHOUERI, por todas as valiosas lições, preciosos conselhos e inspiração para pesquisa. Mesmo sem saber, foi responsável direto para a continuidade e aprofundamento de meus estudos em Direito Tributário, pelos trabalhos realizados e pelos artigos publicados. Meus sinceros agradecimentos.

Aos Professores Roberto Quiroga Mosquera e Heleno Taveira Torres, que, ao aceitarem convite para participarem do Exame de Qualificação deste trabalho, que se encontrava ainda em fase embrionária, deram excelentes recomendações e subsídios essenciais para seu aprimoramento.

A Pinheiro Neto Advogados, firma onde iniciei minha carreira como advogado. Lugar que não me deixa esquecer o quão fundamentais são a humildade, o esforço e a contínua busca pelo melhor resultado. Embora diversos profissionais tenham partilhado importantes lições para minha formação nesses quase dez anos, destaco nominalmente LUCIANA Rosanova Galhardo, Jorge N. Lopes JR. e RAFAel Marchetti Marcondes, que foram os primeiros a me receber, ainda como estagiário, e, muito pacientemente, dedicaram boa parte de seu tempo à minha capacitação.

Aos amigos Jorge Antonio Dias Romero, Vinicius Mattos Barros, William Yuzo Akamine, Rafael Vicente Reicher Soares, Carlos Alberto Elias Mercante, Rubens Barrionuevo Biselli, Diego Alves Amaral Batista, Tiago Eler Silva, Rodrigo de Almeida Manso Vieira e Camila Spadoni Mahfuz. 



\section{RESUMO}

Pretende-se nesta Dissertação tratar dos principais efeitos fiscais decorrentes de operações de incorporação, fusão ou cisão entre pessoas jurídicas num contexto supranacional, tendose como pano de fundo o princípio da neutralidade na alocação dos recursos, segundo o qual, em linhas gerais e sob diferentes perspectivas (import, export, national, ownership ou market neutralities), a forma pela qual o investidor aplica seu capital ou de onde ele provém - seja no âmbito nacional ou internacional - não pode resultar exclusivamente de políticas tributárias, devendo, na medida do possível, ser fruto de uma decisão tomada em cenário neutro, para que dela possa resultar uma alocação eficiente sob o ponto de vista econômico.

A partir da constatação de que as operações de reorganização societária podem estar sujeitas a determinados regimes incentivados de acordo com disposições contidas na legislação tributária doméstica - como, por exemplo, regras de diferimento ("roll-over rules") ou de isenção ("exemption rules") - uma primeira questão será investigar a possibilidade de reorganizações societárias internacionais também se beneficiarem dessa prerrogativa. Comparando-se as disposições contidas em acordos celebrados pelo Brasil, em acordos celebrados por outros países e diretrizes gerais expedidas por organizações internacionais em matéria tributária, analisar-se-á se o regime convencional pode conferir neutralidade às reorganizações societárias internacionais de uma forma geral, ou se, por outro lado, seriam necessárias disposições específicas conhecidas como "Reorganization Clauses".

Confrontaremos então essas análises com as recentes recomendações expedidas no contexto do Projeto BEPS e com as regras tipicamente invocadas para supressão de práticas elusivas em matéria fiscal (simulação, fraude, dolo, etc.), para responder a seguinte questão: a adoção desse tipo de cláusula nos acordos celebrados pelo Brasil seria positiva ou recomendável?

\section{Palavras-chaves}

1. Reorganizações societárias

2. Investimentos cross-border

3. Fusões e aquisições

4. Neutralidade tributária internacional 


\section{SUMMARY}

This study aims at commenting on the main tax effects arising out of merger, consolidation and spin-off transactions carried out among legal entities within a supranational context, based on the tax neutrality principle on the allocation of funds, according to which, in different perspectives (import, export, national, ownership or market neutralities), the way or where an investing entity applies its capital cannot result solely from tax policies, but rather, should result, to the extent as possible, from a neutral decision, so that it may result in an efficient allocation of funds, from an economic point of view.

Based on the assumption that corporate reorganizations may be subject to certain special tax regimes under domestic legislation - for example, "roll-over rules" or "exemption rules" the first point to be addressed regards the possibility of international corporate reorganizations also benefiting from those incentives. Comparing the provisions set forth under the double taxation treaties entered into between Brazil, treaties concluded by other countries and general guidelines issued by international organizations on tax matters, we will analyze whether the conventional regime is able to provide such a tax neutral regime, or whether specific provisions known as "Reorganization Clauses" would be required.

We will confront then these analyzes with recent recommendations issued in the context of the BEPS project and the typically invoked rules suppression elusive practices in tax matters (willful misconduct, fraud, abuse, etc.) to answer the following question: the adoption of such clauses in the agreements signed by Brazil would be positive or recommended?

Keywords

1. Corporate reorganizations

2. Cross-border investments

3. Merger and acquisitions

4. International tax neutrality 


\section{ÍNDICE}

1. InTRODUÇão E APRESENTAÇÃo do TEMA

2. O QUE SERIAM AS “REORGANIZAÇÕES SOCIETÁRIAS”? 18

$\begin{array}{ll}\text { 2.1. Conceito Introdutório } & 18\end{array}$

2.2. As combinações de negócios $\quad 29$

2.3. Reorganizações Societárias que serão objeto deste estudo 34

3. Fundamentos Teóricos QuANTO Às REORGANiZAÇõeS

SOCIETÁRIAS

3.1. Preliminarmente: o conceito jurídico de renda e critérios para sua tributação

3.2. Os ganhos de capital e sua tributação 42

3.3. Os princípios da realização da renda e da neutralidade 45

3.4. Reorganizações societárias conduzidas no Brasil: aspectos fiscais 47

3.5. Reorganizações societárias conduzidas em outros países: Direito comparado

4. O CONTEXTO INTERNACIONAL: FUNDAMENTOS TEÓRICOS 69

4.1. Fundamentos teóricos e as regras de qualificação 69

4.2. Ganhos de capital x Dividendos x Lucros das Empresas x Outros Rendimentos

4.3. Outros fatores de limitação: diferenças temporais, situações triangulares e dupla tributação econômica

4.4. Reorganizações societárias internacionais merecem tratamento diferenciado?

4.4.1. A perspectiva sob o critério da Neutralidade 86

4.4.2. As cláusulas de não-discriminação não são suficientes 89

4.5. As discussões no âmbito da OCDE / ONU 91

4.6. As Diretivas Europeias $\quad 94$ 
5. As Cláusulas de Reorganizações Societárias Em ACORdos para EVitar a DUPla Tributação

5.1. As diferentes Reorganization Clauses 100

$\begin{array}{ll}\text { 5.1.1. Aspectos estatísticos } & 120\end{array}$

$\begin{array}{ll}\text { 5.2. Análise de casos } & 128\end{array}$

5.3. As cláusulas de Reorganizações Societárias são necessárias? 142

5.4. Qual a relevância desse tipo de cláusula no cenário brasileiro? 147

6. A RelaÇÃo entre as CláuSUlas de ReORganizaÇões

Societárias e os Meios para PrevenÇão de Abusos em Matéria

\section{Tributária}

6.1. Um rápido panorama sobre o que se pretende coibir 151

6.2. As ações do G-20 em conjunto com a OCDE: O Projeto BEPS 153

6.3. As cláusulas de reorganização e a prevenção a "estruturas fiscais abusivas"

7. CONSIDERAÇÕes FINAIS 160

$\begin{array}{lll}\text { 8. AnEXos } & 167\end{array}$

9. Bibliografia 176 


\section{INTRODUÇÃo E APRESENTAÇÃO DO TEMA}

Sem sobra de dúvidas Hans Kelsen foi um dos grandes teóricos do Direito no século XX e contribuiu sobremaneira para o desenvolvimento das ciências jurídicas com seus ideais de objetividade, neutralidade e pureza metodológica na investigação do fenômeno jurídico ${ }^{1}$.

Obviamente não temos quaisquer pretensões de questionar seu trabalho ou de revolucionar suas teses, que a nosso ver, são perfeitamente válidas e legítimas para fins da pesquisa acadêmica. Contudo, tomamos desde logo a liberdade de convidar o leitor a permitir certa relativização quanto à pureza metodológica kelseniana para permitir-nos certas incursões multidisciplinares ao longo deste estudo. Afinal, como bem pontua Tercio Sampaio Ferraz Jr., o homem é um "feixe de papeis sociais", cabendo ao Direito "isolá-los e integrá-los num sistema dentro do qual adquirem sentido" 2 .

Não queremos dizer que este será um tratado a respeito de técnicas de administração de empresas, de fundamentos de economia, ou mesmo um compêndio contabilidade / finanças corporativas. Entretanto, como nosso objeto de investigação ao longo deste trabalho serão certas disposições contidas no regime jurídico convencional que se aplicam especificamente a reorganizações societárias realizadas no âmbito internacional (também conhecidas como reorganizações societárias do tipo "cross-border"), naturalmente algumas considerações preliminares a respeito de matérias complementares às ciências jurídicas se revelarão essenciais $^{3}$. Sempre que preciso, portanto, não deixaremos de fazer referência a trabalhos produzidos nas áreas de administração, economia, finanças e contabilidade, e apresentaremos, a título ilustrativo, matérias jornalísticas, fatos relevantes, planilhas e quadros.

Ao longo desta Dissertação, pretendemos aprofundar a análise dos principais efeitos fiscais relacionados a reorganizações societárias, especificamente sob a perspectiva dos Acordos

\footnotetext{
${ }^{1}$ KELSEN, Hans. Teoria Pura do Direito. $7^{\text {a }}$ ed. São Paulo: Martins Fontes, 2006.

${ }^{2}$ FERRAZ Jr., Tercio Sampaio. Introdução ao Estudo do Direito: Técnica, Decisão, Dominação. $4^{\mathrm{a}}$ ed. São Paulo: Ed. Atlas, 2003. p. 156. Miguel Reale também faz interessante ponderação quanto a esse respeito: “(...) a norma jurídica é a indicação de um caminho, porém, para percorrer um caminho, devo partir de determinado ponto e ser guiado por certa direção: o ponto de partida da norma é o fato, rumo a determinado valor." (REALE, Miguel. Teoria Tridimensional do Direito. $5^{\text {a }}$ ed. São Paulo: Saraiva, 2010. pp. 118-119.)

${ }^{3}$ Como aponta Elidie Palma Bifano, "No que tange ao Direito Tributário, em especial, a interação entre os vários ramos do saber é essencial, desde a elaboração da norma, pelo Poder Público, passando por sua aplicação e interpretação." (BIFANO, Elidie. O Direito Tributário e a interdisciplinaridade com outros ramos do saber. Revista Direito Tributário Atual n 30. São Paulo: IBDT/Dialética, 2014. p. 161.)
} 
para Evitar a Dupla Tributação em Matéria de Imposto sobre a Renda ${ }^{4}$.

Não pretendemos nos valer de chavões ou mesmo parecer repetitivos, mas muito se tem falado, não apenas no campo do Direito, como também na imprensa e nas ciências sociais em geral, que o aprimoramento tecnológico que se deu a partir do último quartil do século $\mathrm{XX}$ e a maior rapidez nas telecomunicações foram fatores determinantes para a intensificação do fenômeno da globalização, um processo de intenso intercâmbio social, científico, comercial, cultural e financeiro supranacional ${ }^{5}$.

No contexto desse processo, também as relações empresariais passaram a se desenvolver de forma mais acentuada no ambiente internacional, com o surgimento e consolidação de grandes companhias multinacionais. A partir da década de 1990, especificamente, esse processo de "internacionalização corporativa" resultou num aumento expressivo do número de fusões e aquisições internacionais, como destacado em trabalho publicado pela Organização para a Cooperação e Desenvolvimento Econômico (“OCDE”) sobre esse tema:

\footnotetext{
“(...) A porção de operações de fusão e aquisição internacionais tem crescido significativamente dentre todas as operações do tipo ao longo dos anos 1990. Apesar de ter havido diversas operações de fusão e aquisição envolvendo pequenas e médias empresas, nos anos 1990 viu-se uma explosão e uma expansão geográfica no número e no valor de mega-aquisições entre conhecidas multinacionais. Exemplos recentes incluem a fusão entre a British Petroleum Amoco e a Exxon-Mobil, na indústria do petróleo, a união entre a Daimler-BenzChrysler e a Renault-Nissan no setor automotivo, entre a Astra AB e a Zeneca Group Plc no farmacêutico, e a fusão entre a Vodafone Group Plc e a Airtouch Communications no setor de telecomunicações." 6,7
}

\footnotetext{
${ }^{4}$ Embora José Francisco Rezek e Hildebrando Accioly, respectivamente, entendam que as denominações conferidas aos instrumentos de Direito Internacional Público sejam "de uso livre, indiscriminado, e muitas vezes ilógico (...), livre e aleatório" (REZEK, José Francisco. Direito Internacional Público: Curso Elementar. 11 $1^{a}$ Ed. São Paulo: Saraiva, 2008. pp. 17-18) e que "são inúmeras as denominações utilizadas conforme a sua forma, o seu conteúdo, o seu objeto e o seu fim" (ACCIOLY, Hildebrando. Manual de Direito Internacional Público. 16 a Ed. São Paulo: Saraiva, 2008. p. 132), adotaremos ao longo deste trabalho a terminologia "Convenções" ou "Acordos", que serão tomadas como equivalentes.

${ }^{5}$ TORRES, Heleno Taveira. Direito Tributário Internacional: Planejamento Tributário e Operações Transnacionais. $2^{a}$ ed. São Paulo: Revista dos Tribunais, 2001. pp. 35-36. No mesmo sentido, GALHARDO, Luciana Rosanova. Rateio de Despesas no Direito Tributário. São Paulo: Quartier Latin, 2004. p. 15. BIFANO, Elidie Palma. O planejamento tributário internacional e as boas práticas de governança corporativa nas empresas. Revista de Direito Tributário Internacional. ${ }^{\circ}$ 05. fev. 2007. pp. 63-65.

${ }^{6}$ Tradução livre para o Português. O texto, em sua versão original, em Inglês, é o seguinte:

“(...) The share of cross-border M\&As in overall M\&As has increased dramatically in the 1990s. While there have long been many M\&As targeting SMEs, the 1990s have seen an explosion in, and geographical widening of, the number and value of mega-mergers among well-known multinationals. Recent examples include the British Petroleum - Amoco and Exxon-Mobil mergers in the pertroleum industry, the Daimler-Benz-Chrysler and Renault-Nissan unions in the automotive industry, the Astra AB and Zeneca Group Plc in pharmaceuticals, and the Vodafone Group Plc and Airtouch Communications merger in telecommunications."

${ }^{7}$ KANG, Nam-Hoon; JOHANSSON, Sara. Cross-Border Mergers and Acquisitions: Their Role in Industrial
} 
Consequência direta dessa expansão empresarial internacional e da intensificação dos fluxos financeiros multi-jurisdicionais foi também a maior necessidade de os grupos empresariais promoverem reorganizações societárias em âmbito global. Embora ainda tímidas na década de 1990, ao longo dos últimos anos esses processos têm sido implementados com maior frequência, sobretudo no exterior ${ }^{8}$.

No Brasil, especificamente, além de esse assunto não ser matéria corriqueira, sua análise (sobretudo sob a perspectiva fiscal) não é objeto de estudos e comentários frequentes. Os esparsos trabalhos que trataram desse tema o abordaram de forma relativamente tangencial, em razão do escopo visado pelos autores respectivos ${ }^{9}$. A nosso ver, duas são as principais razões que justificam esse panorama.

A primeira, naturalmente, decorre do fato de o País ainda estar em processo de desenvolvimento, não somente em termos econômico-financeiros, mas em relação ao próprio processo de desenvolvimento e atualização normativa. Apenas para ilustrar o que pretendemos dizer em relação a essa questão, pode-se destacar que somente em 1995 editouse legislação introduzindo a tributação da renda em bases universais para as pessoas jurídicas. Os controles de preços de transferência, por sua vez, somente no ano seguinte. A legislação visando limitar a subcapitalização e a dedução de juros em valores excessivos em relação ao patrimônio da pessoa jurídica com partes vinculadas, por sua vez, somente em 2009. E deixando controvérsias de lado, ainda não temos uma legislação específica que contenha regras antiabuso (General Antiavoidance Rules - "GAARs" - e Specific Antiavoidance Rules - "SAARs”).

A segunda razão pela qual esse tema ainda não se desenvolveu no Brasil de forma

Globalisation, OECD Science, Technology and Industry Working Papers, No. 2000/01, OECD Publishing, Paris. 2000. Disponível em http://www.oecd-ilibrary.org/science-and-technology/cross-border-mergers-andacquisitions_137157251088. Acesso em 24.7.2016.

${ }^{8}$ ENDERS, Dieter; Spengel, Christoph. International Company Taxation and Tax Planning. Alphen aan den Rijn: Wolters Kluwer, 2015. p. 499.

${ }^{9}$ Destacando-se, por exemplo, os trabalhos desenvolvidos por GRISI FILHO, Celso Cláudio de Hildebrand e. Contribuição ao estudo tributário sobre os investimentos internacionais. São Paulo: 2005. Dissertação de Mestrado apresentada à Faculdade de Direito da Universidade de São Paulo.; TAKENOUSHI, Pedro Issao. Reação do Mercado em Fusões \& Aquisições Cross-Border de Firmas Brasileiras. São Paulo: 2012. Dissertação de Mestrado apresentada à Pontifícia Universidade Católica de São Paulo. e BATISTA, Diego Alves Amaral. Silencing the Tower of Babel: A Proposed Solution to the Tax Treatment of Goodwill Across Borders. Special Report. Tax Management Transfer Pricing Report. vol. 22, $\mathrm{n}^{\circ}$ 11. Washington, D.C.: Bloomberg BNA, 2013. 
significativa está relacionada à característica preponderantemente importadora de capitais que o Brasil vem apresentando ao longo dos últimos anos (sendo, portanto, um "Estado de fonte", isto é, apenas recebia investimentos estrangeiros diretos, pouco investindo no exterior), aliada a uma tímida rede de convenções celebradas com outros países para evitar a dupla tributação em matéria de imposto sobre a renda, o que certamente repercute no número de reorganizações societárias internacionais por empresas brasileiras ${ }^{10}$.

Em termos práticos, conduzimos pesquisas independentes em bases de dados públicas, especialmente nos Diários Oficiais dos Estados de São Paulo (https://www.imprensaoficial.com.br), Rio de Janeiro (https://www.ioerj.com.br/portal/), Minas Gerais (http://www.iof.mg.gov.br/), Espírito Santo (http://www.dio.es.gov.br/portal/visualizacoes/diario_oficial), Paraná (http://www.imprensaoficial.pr.gov.br/) e Rio Grande do Sul (http://www.corag.rs.gov.br/doedia), para verificar registros de operações societárias de incorporação, fusão ou cisão entre empresas brasileiras e empresas residentes ou domiciliadas no exterior (reorganizações cross-border). Compilamos, a partir de nossas pesquisas, o seguinte quadro ${ }^{11}$ :

\begin{tabular}{cccc}
\hline $\begin{array}{c}\text { Data de } \\
\text { Publicação }\end{array}$ & Sociedade Incorporadora & Sociedade Incorporada / Cindida & $\begin{array}{l}\text { Jurisdições } \\
\text { Envolvidas }\end{array}$ \\
\hline $\mathbf{1 5 . 1 2 . 2 0 0 5}^{12}$ & Camargo Corrêa Cimentos S.A. & $\begin{array}{c}\text { Gaby1 Holdings, LLC, Gaby2 Holdings, } \\
\text { LLC e Gaby3 Holdings, LLC }\end{array}$ & Estados Unidos \\
\hline $\mathbf{2 . 1 2 . 2 0 0 8}^{13}$ & Marfrig Frigoríficos e Comércio de & Zanzibar Capital, LLC e Blue Horizon & Estados Unidos \\
\hline
\end{tabular}

${ }^{10}$ Nesse sentido, não se pode deixar de considerar que o fato de o Brasil apresentar um mercado interno ainda em formação, com potencial consumidor considerável, altas taxas de retorno de investimento e de juros, custo de mão-de-obra relativamente baixo, disponibilidade de mão-de-obra qualificada e estabilidade política e instituições sólidas, tornam-se não só atrativos para investimentos externos diretos, como bem elucida José Roberto Cunha Junior em sua tese de doutorado, como também, por seu turno, desestimula empresas nacionais a expandirem suas atividades para o exterior. CUNHA JUNIOR, José Roberto. Determinantes da Atratividade de Investimentos Estrangeiros Diretos no Brasil. São Paulo: 2012. Tese de Doutorado apresentada à Faculdade de Economia, Administração e Contabilidade da Universidade de São Paulo.

${ }^{11} \mathrm{Em}$ 2016, foram também anunciadas reorganizações societárias internacionais envolvendo a JBS S.A. e o Banco BTG Pactual S.A., ambos para transferência de linhas de negócios do Brasil para sociedades estrangeiras detidas por essas duas empresas. Entretanto, optamos por não inclui-las no quadro acima por não envolverem especificamente incorporações / cisões internacionais e, no que diz respeito à primeira operação, por não ter sido aprovada até o momento. A descrição dessas operações consta nos respectivos Fatos Relevantes divulgados ao mercado: http://jbss.infoinvest.com.br/ptb/3821/11-05-2016\%20-

\%20Fato\%20Relevante\%20\%28verso\%20final\%29 19\%20hrs.pdf;

http://ri.btgpactual.com/btgpactual/web/download arquivos.asp?id arquivo=008F35BB-4288-41AA-A8339FA2BBE1A194\&conta=28\&s=150031. Acesso em 24.7.2016.

12 Disponível em https://www.imprensaoficial.com.br/DO/BuscaDO2001Documento_11_4.aspx?link=/2005/ empresarial/dezembro/15/pag_0006_DC0LGI7V05CS3eCA0VKT4LKTB9J.pdf\&pagina=6\&data=15/12/2005\&caderno =Empresarial\&paginaordenacao=10006. Acesso em 24.7.2016.

13 Disponível em https://www.imprensaoficial.com.br/DO/BuscaDO2001Documento_11_4.aspx?link=/2008/ empresarial/dezembro/02/pag_0008_94N0U1AOVCVT4e0EFFUMO3T9NGM.pdf\&pagina=8\&data=02/12/2008\&cader 


\begin{tabular}{cccc}
\hline $\begin{array}{c}\text { Data de } \\
\text { Publicação }\end{array}$ & Sociedade Incorporadora & Sociedade Incorporada / Cindida & $\begin{array}{c}\text { Jurisdições } \\
\text { Envolvidas }\end{array}$ \\
\hline $\mathbf{1 2 . 1 . 2 0 1 2}^{14}$ & Alimentos S.A. & Trading Co., LLC & \\
\hline $\mathbf{5 . 7 . 2 0 1 2}^{15}$ & Banco BTG Pactual S.A. & BTG Pactual Banking Ltd. & Ilhas Cayman \\
\hline $\mathbf{1 6 . 1 . 2 0 1 4}^{16}$ & NBCUniversal Networks International & Universal River Holdings LLC & Estados Unidos \\
\hline $\mathbf{1 6 . 1 0 . 2 0 1 5}^{17}$ & Prasil Programadora S.A. & Petrobras International Finance & Luxemburgo \\
\hline & Cencosud Brasil S.A. & Company S.A. & Estados Unidos \\
\hline & $\begin{array}{r}\text { Tabela 1 Publicações identificadas em pesquisas independentes a respeito de } \\
\text { reorganizações societárias do tipo “cross-border" }\end{array}$ &
\end{tabular}

Como se pode notar, em um período de mais de quase dez anos, foram poucas as operações de reorganizações societárias internacionais registradas por empresas brasileiras, sendo todas elas (i) concentradas nos estados de São Paulo e Rio de Janeiro e (ii) envolvendo sociedades anônimas. É claro que a forma de pesquisa é bastante limitada (utilização de palavras-chaves) e nem todos os estados da federação disponibilizam mecanismos eficazes de pesquisas. Contudo, o quadro acima nos permite concluir que, de fato, são poucas as operações de reorganizações societárias internacionais que envolvem empresas brasileiras.

A despeito desse cenário, não se pode deixar de lado a paulatina evolução do Brasil rumo à internacionalização tanto de suas regras jurídico-tributárias, quanto de suas empresas ${ }^{18}$.

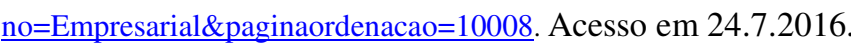

14 Publicação disponível em http://www.jusbrasil.com.br/diarios/33551575/doerj-publicacoes-a-pedido-12-01-2012pg-2. Acesso em 24.7.2016.

15 Disponível em http://www.ioerj.com.br/portal/modules/conteudoonline/view_pdf.php?ie=MTQ5ODM=\&ip=MTI $=\& s=$ YTdhNDNhMGN1ZmM0OTQ2MTg3YjU2MDA2NzlhOWJiMTk=. Acesso em 24.7.2016.

${ }^{16}$ Disponível em http://www.jusbrasil.com.br/diarios/64818368/doerj-publicacoes-a-pedido-16-01-2014-pg-1. Acesso em 24.7.2016.

17 Disponível em https://www.imprensaoficial.com.br/DO/BuscaDO2001Documento_11_4.aspx?link=/2015/ empresarial/outubro/16/pag_0014_8EGATHEOGUPF4e7CHH2U4F3TNQ6.pdf\&pagina=14\&data=16/10/2015\&caderno $=$ Empresarial\&paginaordenacao $=100014$. Acesso em 24.7.2016.

${ }^{18}$ BIFANO, Elidie Palma. Investimentos Brasileiros no Exterior: Os Desafios Tributários das Multinacionais Brasileiras. TÔRRES, Heleno Taveira. Direito Tributário e Ordem Econômica: Homenagem aos 60 anos da ABDF. São Paulo: Quartier Latin, 2010. Sob o ponto de vista da administração, destacam-se ainda, dentre outros, os seguintes trabalhos: ALMEIDA, André; RAMSAY, Jase. A Ascensão das Multinacionais Brasileiras: O Grande Salto de Pesos-Pesados Regionais a Verdadeiras Multinacionais. Rio de Janeiro: Elsevier/Campus, 2009. URBAN, Tatiana Proença. O Processo de Internacionalização de uma Multinacional Brasileira. São Paulo: 2006. Dissertação de Mestrado apresentada à Faculdade de Economia, Administração e Contabilidade da Universidade de São Paulo. KRAUS, Pedro Guilherme. Modelo de Internacionalização de Empresas Produtoras Exportadoras Brasileiras. Florianópolis: 2000. Tese de Doutorado apresentada à Faculdade de Engenharia da Universidade Federal de Santa Catarina. BARRETO, Antonio; ROCHA, Ângela. A Expansão das Fronteiras: Brasileiros no Exterior. ROCHA, Ângela (Org.). As Novas Fronteiras: A Multinacionalização das Empresas Brasileiras. Rio de Janeiro: Mauad, 2003. 
Relativamente ao primeiro aspecto, por exemplo, destaca-se o processo de convergência das regras contábeis locais ("BRGAAP”) aos padrões contábeis internacionais baseados nos princípios do International Financial Reporting Standards ("IFRS"), iniciado com a publicação da Lei $n^{\circ} 11.638$, de 28.12.2007 (“Lei 11.638/07”) e da Lei n 11.941, de 27.5.2009 (“Lei 11.941/09”). O disciplinamento fiscal posteriormente instituído pela Medida Provisória n 627, de 11.11.2013 (“MP 627/13”) e pela Lei n 12.973, de 13.5.2014 (“Lei 12.973/14") conferiu ao Direito Tributário pátrio maiores pontos de aproximação às discussões mantidas no cenário internacional. Isso, naturalmente, tem o condão de aumentar o intercâmbio de informações, de experiências econômico-financeiras-contábeis e fiscais.

Já em relação ao segundo ponto, destacamos os estudos promovidos anualmente pelo Banco Central do Brasil quanto aos capitais estrangeiros investidos no Brasil e aos capitais brasileiros no exterior ${ }^{19}$, que demonstram um crescimento significativo no volume de investimentos diretos em empresas estrangeiras por brasileiros. Para se ter dimensão desse crescimento, no ano-calendário de 2010 a proporção entre investimentos diretos estrangeiros no Brasil e investimentos brasileiros detidos em participações societárias no exterior era de 3,55:1. No ano seguinte, essa razão caiu para 3,40:1, passando, em 2012, para 2,73:1. Em 2013, tais valores passaram a ser de 2,36:1 e, em 2014 - ano da última pesquisa já consolidada - atingiu o menor patamar, de 2,29:1.

Embora esse não seja fator determinante para justificar que os investimentos brasileiros no exterior têm se tornado mais relevantes, os índices acima refletem maior presença de capitais brasileiros no exterior, levando, eventualmente, à necessidade de reorganizações internacionais. Esse, por exemplo, foi o próprio caso envolvendo a Petróleo Brasileiro S.A., destacado na Tabela 1, acima, como se pode constatar a partir do Fato Relevante divulgado pela empresa em $11.12 .2013^{20}$ e certas notícias publicadas pela imprensa, à época ${ }^{21}$.

\footnotetext{
${ }^{19}$ BANCO CENTRAL DO BRASIL. Capitais Brasileiros no Exterior (CBE): Ano-Base 2013. Disponível em http://www4.bcb.gov.br/rex/cbe/port/cbe.asp. Acesso em 25.7.2016. __ Censo de Capitais Estrangeiros no País: Resultados para $2013 . \quad$ Disponível em http://www.bcb.gov.br/rex/censoce/port/censo.asp?idpai=cambio. Acesso em 25.7.2016.

20 Disponível em http://www.investidorpetrobras.com.br/pt/comunicados-e-fatos-relevantes/fato-relevanteincorporacao-de-empresas-pela-petrobras. Acesso em 25.7.2016.

$21 \quad$ Por exemplo, http://economia.estadao.com.br/noticias/geral,petrobras-incorpora-duas-empresas-pifco-ecrsec,169984e; $\quad$ http://www1.folha.uol.com.br/mercado/2013/12/1386716-petrobras-incorpora-parte-de-subsidiariainternacional.shtml; e http://veja.abril.com.br/economia/petrobras-fecha-subsidiarias-em-paraisos-fiscais/. Acesso em 25.7.2016.
} 
Mais recentemente, reconhecendo a importância de investimentos brasileiros no exterior, a Comissão de Valores Mobiliários ("CVM") chegou a autorizar, por meio da Instrução CVM $n^{\circ}$ 578, de 30.8.2016 (“ICVM 578/16”), dentre outras medidas, que Fundos de Investimentos em Participações (“FIPs”) brasileiros possam manter em seu portfólio até $20 \%$ de seu capital em ativos no exterior, desde que tais ativos tenham as mesmas características dos ativos locais elegíveis para investimento. Note-se que até então o artigo 35, inciso VI, alínea "a", da Instrução CVM n 391, de 16.7.2003 (“ICVM 391/03”) vedava expressamente que FIPs brasileiros investissem em ativos no exterior.

A atualidade e importância desse tema também se justifica nos diversos seminários regionais e Congressos Anuais patrocinados pela International Fiscal Association ("IFA") 22, destacando-se, por exemplo, os congressos de 2005, ocorrido em Buenos Aires (Painel 2 Tax treatment of international acquisitions of businesses ${ }^{23}$ ), de 2011, em Paris (Painel 1 Cross-border business restructuring ${ }^{24}$ ), e de 2015, em Basel (Seminário E - Cross-border mergers of companies ${ }^{25}$ ).

Sob a perspectiva brasileira, tem-se notado também crescente interesse por operações envolvendo reorganizações societárias internacionais, destacando-se, por exemplo, o caso de incorporações de sociedades controladas no exterior comentada por Luciana Rosanova Galhardo no seminário "8th Annual U.S. - Latin America Tax Planning Strategies" de $2015^{26}$, ou mesmo o fato de Luís Eduardo Schoueri ter dedicado um capítulo inteiro de sua obra a respeito da dedutibilidade fiscal de despesas de amortização de ágio aos casos envolvendo incorporação de sociedades no exterior ${ }^{27}$.

Como veremos ao longo deste trabalho, no início da década de 1970, visando estimular setores econômicos estratégicos e incentivar o desenvolvimento de empresas no Brasil, concedeu uma série de regimes especiais e benefícios para as operações de reorganização societária em geral (entendidas, grosso modo, como incorporações, fusões ou cisões). Ao

\footnotetext{
${ }^{22}$ Bangalore (Julho/2015); Bogotá (Junho/2014); Toronto (Maio/2014); Varsóvia (Novembro/2012); Tóquio (Julho/2011); Moscou (Novembro/2010) e Londres (Setembro/2010).

${ }^{23}$ Disponível em https://www.ifa.nl/CongresDocumenten/2005S2.pdf. Acesso em 25.7.2016.

${ }^{24}$ Disponível em https://www.ifa.nl/CongresDocumenten/Issues\%20Papers\%202011S1.pdf. Acesso em 25.7.2016.

${ }^{25}$ Disponível em https://www.ifa.nl/CongresDocumenten/2015SemEShortDesc.pdf. Acesso em 25.7.2016.

${ }^{26}$ GALHARDO, Luciana Rosanova. Amortization of intangible assets in Brazil: Strategies and perspectives. Miami. 8th Annual U.S. - Latin America Tax Planning Strategies, 2015.

${ }^{27}$ SCHOUERI, Luís Eduardo. Ágio em Reorganizações Societárias: Aspectos Tributários. São Paulo: Dialética, 2012.
} 
longo dos anos, tais estímulos foram modificados e adaptados conforme as necessidades do mercado doméstico. Contudo, em termos de reorganizações societárias internacionais envolvendo investimentos externos detidos por empresas brasileiras, não há quaisquer diplomas normativos nesse sentido.

Pode-se, de fato, contrapor essa afirmativa com a alegação de que, nessas situações, poderiam ser aplicadas as mesmas regras fiscais previstas para reorganizações conduzidas em âmbito interno, bem como os princípios gerais que orientam a tributação. Contudo, não se pode deixar de considerar que referida abordagem (i) lida apenas com uma das "pontas" da operação (perspectiva brasileira, apenas); (ii) não mitiga ineficiências, não confere absoluta neutralidade à operação e, principalmente, não lida com hipóteses de dupla ou pluritributação; e (ii) não se encontra expressamente amparada por um dispositivo normativo no ordenamento jurídico brasileiro e decorreria de uma solução por integração ${ }^{28}$.

Mesmo quando analisados os acordos celebrados pelo Brasil com outros países em termos de matéria fiscal, não há dispositivos que tratem dessa questão. É uma política diferente, por exemplo, daquela encontrada em outros acordos celebrados no exterior, como ilustra o item XIII (8) do Acordo celebrado em 1980 entre Estados Unidos e Canadá:

\footnotetext{
"8. Quando um residente de um Estado Contratante alienar propriedade no curso de uma organização empresarial, reorganização, fusão, cisão ou operação semelhante, e os lucros, ganhos ou rendimentos em relação a tal alienação não são reconhecidos para efeitos de tributação nesse Estado, se solicitado a fazê-lo pela pessoa que adquire a propriedade, a autoridade competente do outro Estado Contratante pode concordar em adiar o reconhecimento do lucro, ganho ou renda com relação a essa propriedade para fins de tributação nesse outro Estado a fim de evitar a dupla tributação, nos termos e condições impostos por essa autoridade competente, até o momento e forma estipulados no acordo." 29
}

\footnotetext{
${ }^{28} \mathrm{O}$ artigo 21 da Lei ${ }^{\circ}$ 9.249, de 26.12.1995 (“Lei 9.249/95”) trata apenas das hipóteses envolvendo “pessoas jurídicas". Via de regra, quando a legislação fiscal brasileira trata de não-residentes no País, não se costuma adotar a referência a "pessoa jurídica", até mesmo pelo fato de essa denominação decorrer de uma ficção criada pela legislação doméstica. Sobre essa questão, aliás, referimo-nos ao artigo de SCHOUERI, Luís Eduardo; BARBOSA, Mateus Calicchio. A Persona e o Direito: entre a Realidade e a Ficção das Pessoas Jurídicas. Revista Direito Tributário Atual $n^{\circ}$ 30. São Paulo: IBDT/Dialética, 2014.

${ }^{29}$ Tradução livre para o Português. O texto, em sua versão original em Inglês é o seguinte:

"8. Where a resident of a Contracting State alienates property in the course of a corporate organization, reorganization, amalgamation, division or similar transaction and profit, gain or income with respect to such alienation is not recognized for the purpose of taxation in that State, if requested to do so by the person who acquires the property, the competent authority of the other Contracting State may agree, in order to avoid double taxation and subject to terms and conditions satisfactory to such competent authority, to defer the recognition of the profit, gain or income with respect to such property for the purpose of taxation in that other State until such time and in such manner as may be stipulated in the agreement."
} 
Nosso objetivo com o presente estudo será, basicamente, analisar disposições semelhantes a essa, conhecida como "Reorganization Clauses", ou "Cláusulas de Reorganizações Societárias". Sem dúvida se trata de uma disposição que visa conferir neutralidade às operações de fusão, incorporação ou cisão de empresas no âmbito transnacional. Analisaremos suas formas, estrutura, relação com as operações de reorganizações societárias e, principalmente, a necessidade e/ou conveniência de sua implementação para fins jurídicofiscais brasileiros.

Não deixando tampouco de lado as recentes questões muito debatidas em âmbito internacional quanto à necessidade de adoção de mecanismos para coibir práticas ditas elusivas, "abusivas" ou mesmo "contrárias ao bom Direito" (o tão citado Base Erosion and Profit Shifting Project - mais conhecido por seu acrônimo - "BEPS”), também faremos uma análise comparativa desses dispositivos convencionais à luz dessas discussões para verificar se a adoção de tais mecanismos poderia eventualmente facilitar a criação e implementação de estruturas ou técnicas que, atualmente, vêm sendo cada vez mais questionadas / repelidas.

Para tanto, iniciaremos nossa incursão visando responder uma questão relativamente simples: "O que são as 'reorganizações societárias"? A partir dessa resposta, fundamentada com base na doutrina jurídica, textos produzidos por economistas, administradores e contadores, apresentaremos um panorama teórico quanto aos aspectos ficais de relevo nessas operações. Buscaremos no conceito de renda e no modelo "SchanzHaig-Simons" (“SHS") as causas pelas quais tradicionalmente "rendimentos" e "ganhos de capital" recebem tratamento jurídico distinto em diversas legislações domésticas.

No Brasil, esses regimes diferencias de tributação podem ser exemplificados pelo diferimento de ganhos por compra vantajosa ou, no caso de não-residentes (tributados como pessoas físicas residentes no Brasil), da aplicação da "roll-over rule" de que trata a Instrução Normativa n 11, de 21.2.1996 (“IN 11/96”). No Direito comparado, diversos são os casos em que os ganhos auferidos em reorganizações societárias podem ser submetidos a regimes de diferimento ainda mais amplos ou mesmo a sistemas que contêm regras isentivas.

No âmbito da União Europeia, por exemplo, foi editada pelo Conselho Europeu, em 23.7.1990, a Diretiva 434 (Diretiva 90/434/EEC), visando conferir ampla neutralidade para as operações conduzidas no âmbito desse bloco, para, com isso, se evitar possíveis limitações 
ao fluxo de recursos e distorções decorrentes da legislação fiscal interna de cada Estadomembro que pudesse eventualmente mitigar a liberdade de reorganização societária. Essa diretiva, com o passar dos anos, acabou sendo aprimorada até resultar em um verdadeiro regime unificado de neutralidade fiscal para reorganizações societárias internacionais conduzidas dentro desse bloco econômico.

Nesse contexto é que nos propomos a analisar ao longo deste trabalho, de forma específica, as reorganizações societárias internacionais tipicamente conhecidas como "cross-border", isto é, aquelas envolvendo duas empresas em diferentes jurisdições. Embora na doutrina possa-se encontrar trabalhos que dividam tais operações entre reorganizações "legitimamente" cross-border - aquelas que envolvam mais de uma jurisdição - e reorganizações societárias do tipo “foreign-to-foreign", que envolvem uma única jurisdição, mas com efeitos em outros países, para fins do presente trabalho englobaremos sob o conceito "reorganizações societárias internacionais" tanto uma figura quanto a outra, sendo suficiente para tanto a presença de um "elemento de estraneidade".

Como fundamentos teóricos necessários para a continuidade da análise proposta, apresentaremos as principais regras para qualificação de rendimentos à luz dos acordos de tributação, as questões ligadas à função dessas convenções e a perspectiva da neutralidade internacional. Com esse arcabouço teórico, passaremos à análise das "Cláusulas de Reorganizações Societárias" ("Reorganization Clauses") propriamente ditas e proporemos uma sistematização para seu estudo.

Com isso, seremos capazes de responder às duas indagações a partir das quais se originou o presente trabalho: (i) tais cláusulas seriam justificáveis para fins fiscais brasileiros?; e (ii) elas poderiam levar à adoção de práticas elusivas e de estruturas “contrárias ao bom Direito”?

Desde já esclarecemos, contudo, que não serão tratados neste estudo aspectos que se relacionam à matéria apenas de forma indireta, como, por exemplo, regras de tributação de lucros auferidos por controladas ou coligadas estrangeiras ("CFC rules") ${ }^{30}$, de transparência fiscal internacional ${ }^{31}$, reconhecimento de ativos, goodwill, ou mesmo eventuais obrigações

${ }^{30}$ ROCHA, Sérgio André. Tributação de Lucros Auferidos no Exterior (Lei n ${ }^{\circ}$ 12.973/14). São Paulo: Dialética, 2014.

${ }^{31}$ BIANCO, João Francisco. Transparência Fiscal Internacional. São Paulo: Dialética, 2007. 
acessórias que decorram de quaisquer dessas outras regras de tributação. Tampouco serão objeto de estudo os aspectos práticos ou procedimentais relacionados às operações de incorporação, fusão ou cisão.

Limitaremos o objeto deste trabalho, pois, à investigação quanto à aplicação do princípio da neutralidade em operações de reorganizações societárias internacionais, sob a perspectiva das cláusulas de reorganizações societárias presentes em alguns acordos para evitar a dupla tributação em matéria de imposto sobre a renda. 


\section{CONSIDERAÇÕES FINAIS}

Com base em todo o anteriormente exposto, pode-se sumarizar as principais questões discutidas ao longo deste trabalho nos seguintes pontos:

(i) as reorganizações societárias internacionais ("cross-border") têm sido um fenômeno cada vez mais presente na economia globalizada, tendo sido um assunto já destacado pela OCDE no início dos anos 1990 e sido um tema debatido em diversos painéis da IFA;

(ii) o Brasil, tradicionalmente, tem se mostrado um País preponderantemente exportador de capitais; mas ao longo dos últimos anos tem-se também verificado, por outro lado, um crescente fluxo de investimentos realizados por empresas locais no exterior. Referido intercâmbio tem levado consequentemente a uma maior necessidade de reorganização desses investimentos estrangeiros, surgindo daí a necessidade, em certos casos, de implementação das reorganizações societárias de que trata este trabalho. É certo que não são operações recorrentes no cotidiano empresarial brasileiro, mas a introdução de um novo sistema contábil alinhado aos parâmetros internacionalmente aceitos (IFRS) e a modernização / internacionalização da legislação fiscal doméstica, de certo modo, têm em nosso entendimento contribuído para o crescimento no número de operações desse tipo. $\mathrm{Na}$ Introdução deste trabalho apresentamos alguns casos;

(iii) ao tratar de "reorganizações societárias" internacionais, a primeira questão que se coloca é justamente o conceito de "reorganizações societárias". Apesar de bastante frequente o uso dessa expressão, seu conceito não é suficientemente claro, seja na legislação, seja na doutrina, tendo sido poucos os autores, aliás, a enfrentar essa questão. Como regra geral, diversos ordenamentos jurídicos acabam recorrendo a formas tipológicas para englobar sob o conceito de "reorganizações societárias" as operações de incorporação, fusão, cisão, aumento e redução de capital. Contabilmente, trabalha-se com o conceito de "combinações de negócios", que envolvem a análise da operação sob a perspectiva do "controle”. Contudo, essa definição acaba sendo bastante limitada. De forma genérica, pode-se definir "reorganizações societárias" como operações pelas quais empresas buscam facilitar circulações de riqueza, tornar céleres os processos de aglutinação ou separação patrimonial, ou mesmo se recuperar; 
(iv) no âmbito internacional - isto é, no qual haja elementos de "estraneidade" - a classificação sugerida por Carlo Garbarino com base na Merger Directive de 2009 (Diretiva 2009/133/CE) para as reorganizações societárias se mostra bastante didática e simples: (a) reorganizações internacionais de primeiro grau, que envolvem transferências de ativos e passivos; $(b)$ reorganizações internacionais de segundo grau, que envolvem transferências de participações societárias; e $(c)$ reorganizações internacionais de terceiro grau, que envolvem especificamente operações de fusão, cisão ou incorporação de sociedades;

(v) no contexto de operações de reorganizações societárias, ganhos de capital ou rendimentos tributáveis podem surgir para as partes envolvidas no negócio ou para seus controladores (sócios / acionistas). Ao comentar sobre o conceito jurídico de renda e as possibilidades de sua tributação, a doutrina costuma diferenciar rendimentos de ganhos de capital. Para fins das operações analisadas neste trabalho, referida diferenciação acaba se mostrando relevante, na medida em que a tributação depende da observância, de forma mais incisiva, os princípios da realização da renda (isto é, a efetiva monetização dos recursos) e da neutralidade (segundo o qual as escolhas devem ter a menor distorção possível em razão dos efeitos fiscais correspondentes);

(vi) no Brasil, a legislação fiscal apresenta alguns mecanismos que, aplicados no contexto das reorganizações societárias, indicam a preocupação com a observância desses dois princípios, podendo ser citados, por exemplo, diversas medidas editadas ao longo da década de 1970 para incentivar tais operações (Decreto-Lei $\mathrm{n}^{\circ}$ 1.115, de 24.7.1970, Decreto-Lei $\mathrm{n}^{\circ}$ 1.182, de 16.7.1971, dentre outros), algumas isenções instituídas para ganhos de capital auferidos na alienação de participações societárias (Decreto-Lei n ${ }^{\circ}$ 1.510, de 27.12.1976), e a regra de manutenção de custo histórico para pessoas físicas ("roll-over rule") consubstanciada na IN 11/96;

(vii) no caso de operações realizadas no Brasil por não-residentes, em linhas gerais a tributação de ganhos de capital recebe o mesmo tratamento aplicável às pessoas físicas residentes, nos termos do artigo 18 da Lei 9.249/95 e do artigo 26 da IN 208/02 - ressalvadas as isenções e reduções de tributo que não se aplicam automaticamente a não-residentes. Em todo caso, uma particularidade prevista na legislação brasileira é a tributação de ganhos de capital auferidos na alienação de bens localizados no País, conforme o disposto no artigo 26 
da Lei 10.833/03. Apesar das (duras) críticas que lhe podem ser feitas, como pontua a doutrina, diversos países passaram a adotar mecanismos semelhantes, sobretudo após o caso "Vodafone” julgado pela Suprema Corte da Índia em 2012 (por exemplo, Argentina, Chile, Colômbia, Espanha, México);

(viii) analisando-se as disposições contidas na legislação interna de outros países a respeito do tratamento fiscal conferido em operações de reorganizações societárias, constata-se também que a grande maioria dos ordenamentos buscam conferir regimes neutros, ainda que de forma condicionada e/ou sujeita à observância de determinados critérios ou "razões empresariais";

(ix) contudo, quando essas operações de reorganizações societárias ocorrem no âmbito internacional, especialmente no caso em que haja acordos para evitar a dupla tributação em matéria de imposto sobre a renda, algumas limitações podem ser verificadas. Por exemplo, conflitos de qualificação (ganhos de capital / dividendos / lucros das empresas / outras receitas), situações triangulares, casos de dupla (ou plurti) tributação econômica, além dos próprios descompassos relacionados à tributação (timing mismatches) nos diversos Estados envolvidos. Tais situações dificilmente são endereçadas pelo arcabouço jurídico presente na maior parte das convenções e podem limitar a aplicação do princípio da neutralidade;

(x) referido princípio, vale dizer, apresenta contornos ainda mais significativos no contexto internacional, sendo diversos os trabalhos acadêmicos jurídicos e econômicos que buscam formular teorias e encontrar soluções para a criação de um ambiente internacional fiscalmente neutro, resultando na maior integração econômica;

(xi) a nosso ver, as reorganizações societárias internacionais merecem tratamento fiscal diferenciado, assim como ocorre no caso de operações conduzidas localmente. Para tanto, considerando as atuais disposições presentes em diversos acordos bilaterais e ConvençõesModelos, acaba se mostrando relevante a inclusão de dispositivos específicos para endereçar a questão - aí que surgem as cláusulas de reorganizações societárias. Até mesmo porque, como visto ao longo deste trabalho, as meras disposições relativas ao princípio da nãodiscriminação por vezes se mostram insuficientes para lidar com as adversidades surgidas em algumas dessas operações; 
(xii) é verdade que a OCDE tem reconhecido em diversos relatórios e vem se manifestando há vários anos sobre a relevância das reorganizações societárias internacionais, mas não chegou a inserir disposições expressas na sua Convenção-Modelo ou nos seus Comentários a esse documento. No âmbito da ONU, por sua vez, apesar de constar no artigo 13 (5) de sua Convenção-Modelo uma cláusula que autoriza a tributação de ganhos de capital no Estado da Fonte quando auferidos em razão da alienação de participações societárias qualificadas, como se se tratasse de uma tentativa de equiparar tais investimentos a empresas residentes, a questão passou a ser endereçada de forma mais avançada do que na OCDE, já que em 2011 fez-se constar um comentário específico nos Comentários a respeito das reorganizações societárias internacionais e sua relação com esse dispositivo. Reconhece a ONU que se os Estados Contratantes pretenderem manter tratamento fiscalmente neutro nesses casos, nada os impediria de pactuar uma cláusula específica para as reorganizações societárias;

(xiii) as Diretivas Europeias que endereçam as reorganizações societárias internacionais (Merger Directives), ainda que limitadas e sujeitas a certas críticas por parte da doutrina, se mostraram, a nosso ver, pioneiras e bastante positivas, sobretudo por terem levado ao aumento no número dessas operações no âmbito do bloco. Tal fato, mesmo que empírico, não deixa de confirmar que a neutralidade fiscal pode desempenhar um papel relevante na integração econômica e no fomento às reorganizações societárias;

(xiv) a partir de nossas pesquisas em acordos que contivessem cláusulas de reorganizações societárias, identificamos 139 convenções com cláusulas de reorganização societária, que, embora apresentem características diversas, podem ser agrupadas em quatro grandes categorias: (a) cláusulas que tratam de meros deveres registrais (24 convenções); $(b)$ cláusulas de reorganização ligadas a trocas de participações societárias em empresas com atividades preponderantemente imobiliárias (53 convenções); (c) cláusulas que constituem exceção às regras de participações qualificadas (27 convenções); e (d) cláusulas de reorganização de escopo abrangente (35 convenções);

(xv) o primeiro grupo é composto principalmente por acordos celebrados pela França com antigas colônias africanas durante as décadas de 1960 e 1970, e essas convenções apresentam uma estrutura bastante simplificada, dispondo que os tributos devidos quando do registro de operações de reorganizações societárias são devidos no Estado em que a sociedade sobrevivente na operação seja residente para fins fiscais. Pudemos identificar três "modelos" 
para essa cláusula, mas a variação entre elas é praticamente pontual;

(xvi) a segunda categoria, por sua vez, abrange convenções relativamente homogêneas entre si, e apresentam verdadeiras regras de exceção ao artigo 13 (4) da Convenção-Modelo da OCDE, que trata da possibilidade de tributação no Estado de Fonte dos ganhos de capital decorrentes da alienação de ações em sociedades cujos rendimentos sejam preponderantemente derivados de atividades imobiliárias;

(xvii) já o terceiro conjunto traz diversos tipos de acordos diferentes entre si. Tratam-se de exceções aos casos de tributação no Estado da Fonte caso haja alienações de participações qualificadas. Podem se apresentar sob forma puramente distributiva ou material. A diferença é que no primeiro caso limita-se apenas a definir o Estado competente para tributar os resultados da reorganização societária (exemplo, acordos celebrados por França e Japão). Já as cláusulas materiais preveem regras mais complexas, apresentando ainda, na maioria dos casos, condicionantes para a aplicação do regime de neutralidade fiscal;

(xix) o quarto grupo, por fim, abrange as cláusulas de reorganização societária de escopo abrangente, sendo o exemplo mais emblemático o caso do artigo XIII (8) da convenção celebrada em 1980 entre Estados Unidos e Canadá;

(xx) de forma geral, a análise estatística dos acordos que apresentam cláusulas de reorganizações societárias nos permite concluir que esses dispositivos costumam ser adotados especialmente por países europeus, membros da OCDE, com IDH considerado muito alto (acima de 0,8). Entretanto, não é possível se estabelecer uma relação certa entre o número de acordos celebrados por uma país e o número de acordos que contenham esses dispositivos, o que, em outras palavras, quer dizer que o número de acordos celebrados por um país para evitar a dupla tributação em matéria de imposto sobre a renda não acaba sendo um fator determinante para a celebração de acordos com cláusulas de reorganizações societárias. Por outro lado, o que se pode constatar neste trabalho é que cada um dos quatro grandes grupos acima descritos teve um período de "auge", ou seja, pode-se identificar períodos bastante definidos em que cada tipo de cláusula passou a ser mais frequente atualmente, as mais recorrentes têm sido as cláusulas relativas ao segundo grupo (participações em sociedades imobiliárias); 
(xxi) poucos casos endereçaram expressamente a questão envolvendo a aplicação de cláusulas de reorganizações societárias em acordos para evitar a dupla tributação em matéria de imposto sobre a renda, tendo sido identificados, em nossas pesquisas, seis casos no total, sendo cinco julgados na Índia, país que possui apenas um acordo com tal disposição (acordo Índia - Países Baixos, de 1988);

(xxii) já caminhando para as conclusões, as análises realizadas ao longo deste trabalho nos permitiram concluir que a celebração de acordos para evitar a dupla tributação em matéria de imposto sobre a renda com cláusulas de reorganizações societárias acaba se mostrando muito mais uma questão de política fiscal dos Estados envolvidos no contexto da negociação desses instrumentos bilaterais. Contudo, jurídica e economicamente, não se pode deixar de considerar que esses dispositivos podem se revelar bastante positivos, já que, no primeiro caso, além da segurança jurídica e neutralidade, seriam minimizadas as diversas ineficiências apontadas em relação às operações de reorganizações societárias no contexto transnacional, como conflitos de qualificação, descompassos temporais, situações triangulares, etc. Economicamente, apesar de não ser pacífica na doutrina a relação entre desenvolvimento econômico e a quantidade de acordos para evitar a dupla tributação, não se pode deixar de considerar dois exemplos específicos comentados ao longo do item 5.3, envolvendo Canadá e Hong Kong, que após passarem a adotar as reorganization clauses com maior frequência em seus acordos, viveram períodos de forte desenvolvimento econômico;

(xxiii) nenhum acordos celebrados pelo Brasil possui cláusula de reorganização societária, mas considerando as questões apontadas no item (ii) e a maior presença de capitais brasileiros investidos em participações societárias no exterior, quer nos parecer que poderia se mostrar positiva a adoção desses mecanismos nas convenções assinadas pelo País, até mesmo como uma forma de estimular tais tipos de operação com a devida segurança jurídica e neutralidade fiscal; e

(xxiv) mesmo diante dos recentes debates envolvendo o Projeto BEPS e as tentativas de prevenção de situações reputadas como evasivas, elisivas ou mesmo "agressivas", entendemos que as cláusulas de reorganizações societárias não devem ser reputadas como instrumentos de planejamento tributário, mas sim mecanismos que contribuem para esses esforços, algumas inclusive apresentando mecanismos próprios para negativa de benefícios convencionais em caso de motivos preponderantemente evasivos ou elisivos. Embora não 
seja a maioria dos acordos que possua mecanismos próprios antiabuso, a própria dinâmica de aplicação convencional, com suas restrições de LoB e de beneficiário efetivo também pode justificar a negativa de aplicação do em casos que efetivamente não correspondam a reorganizações societárias válidas e legítimas. 


\section{Anexos}

NOTA PRÉVIA: Os anexos abaixo foram baseados em pesquisas independentes que realizamos nos portais eletrônicos disponibilizados pelo International Bureau of Fiscal Documenttion ("IBFD” http://online.ibfd.org/kbase/) e pelo World Legal Information Institute (“WLII” - http://www.worldlii.org/). A partir dos dados que coletamos com as palavras-chaves "merger", "reorganization", "reorganisation", "incorporation" e "group of companies", confrontamos os resultados obtidos com outras pesquisas desenvolvidas na doutrina a respeito desse tema ${ }^{296}$. A data de corte para a pesquisa foi 18.9.2016.

As principais divergências foram as seguintes: (i) atualização das pesquisas, levando em consideração dados posteriores a 2014 (dados do último levantamento realizado); (ii) desconsideração de acordos multilaterais, tendo em vista o escopo de nosso estudo; e (iii) divergências quanto à numeração de certos artigos, sobretudo no Anexo I, tendo em vista que nos baseamos na redação original dos acordos mencionados (quando isso não ocorrer, indicaremos em observações específicas).

$$
* . * * . * *
$$

ANEXO I: Acordos que contêm cláusulas de reorganizações societárias que tratam apenas de obrigações relativas a registros

\begin{tabular}{|c|c|c|c|c|c|}
\hline $\begin{array}{c}\text { Estado } \\
\text { Contratante } 1\end{array}$ & $\begin{array}{c}\text { Estado } \\
\text { Contratante 2 }\end{array}$ & $\begin{array}{c}\text { Ano de } \\
\text { Assinatura }\end{array}$ & Vigente? & Artigo & Observações \\
\hline França & Madagascar & 1962 & Não & 35 & \multirow{10}{*}{$\begin{array}{l}\text { Além de esses acordos terem sido } \\
\text { celebrados apenas pela França com } \\
\text { suas antigas colônias (ou, no caso } \\
\text { particular de Mauritânia e Senegal, } \\
\text { entre as próprias ex-colônias), todos } \\
\text { eles dispõem sobre meios para } \\
\text { evitar a dupla tributação em matéria } \\
\text { de imposto sobre renda e versam } \\
\text { também sobre outros tributos } \\
\text { (propriedades, heranças, sucessões }\end{array}$} \\
\hline França & Níger & 1965 & Sim & 35 & \\
\hline França & Burquina Faso & 1965 & Sim & 35 & \\
\hline \multirow{2}{*}{ França } & \multirow{2}{*}{ Senegal } & 1965 & Não & 35 & \\
\hline & & 1974 & Sim & 35.2 & \\
\hline \multirow{2}{*}{ França } & \multirow{2}{*}{ Camarões } & 1965 & Não & \multirow{2}{*}{35} & \\
\hline & & 1976 & Sim & & \\
\hline França & Costa do Marfim & 1966 & Sim & 35 & \\
\hline França & Gabão & 1966 & Não & 35 & \\
\hline França & Mauritânia & 1967 & Sim & 35.2 & \\
\hline \multirow{2}{*}{ França } & \multirow{2}{*}{ Congo } & 1967 & Não & 35 & \multirow{2}{*}{$\begin{array}{l}\text { e registros de documentos - stamp } \\
\text { taxes). }\end{array}$} \\
\hline & & 1987 & Sim & 24.3 & \\
\hline \multirow{2}{*}{ França } & \multirow{2}{*}{ Argélia } & 1968 & Não & 37.2 & \multirow{4}{*}{$\begin{array}{l}\text { Os artigos destacados neste ANEXO, } \\
\text { especificamente, constam na seção } \\
\text { de "outros tributos de registros que } \\
\text { não relativos a documentos [stamp }\end{array}$} \\
\hline & & 1982 & Não & 31.2 & \\
\hline França & $\begin{array}{c}\text { República } \\
\text { Centro-Africana }\end{array}$ & 1969 & Sim & 35 & \\
\hline França & Comores & 1970 & Não & 34 & \\
\hline
\end{tabular}

${ }^{296}$ L'HOTELLERIE-FALLOIS, Domingo J. Jiménez-Valladolid. op. cit. p. 399 e sgs. 


\begin{tabular}{|c|c|c|c|c|c|}
\hline $\begin{array}{c}\text { Estado } \\
\text { Contratante } 1\end{array}$ & $\begin{array}{c}\text { Estado } \\
\text { Contratante } 2\end{array}$ & $\begin{array}{c}\text { Ano de } \\
\text { Assinatura }\end{array}$ & Vigente? & Artigo & Observações \\
\hline França & Maiote & 1970 & Não & 34 & \multirow{8}{*}{$\begin{array}{l}\text { taxes] e sucessões". Ainda assim, } \\
\text { entretanto, são regras que nos } \\
\text { permitem qualifica-los como } \\
\text { cláusulas de reorganizações } \\
\text { societárias. }\end{array}$} \\
\hline França & Togo & 1971 & Sim & 35.2 & \\
\hline Senegal & Mauritânia & 1971 & Sim & 27 & \\
\hline França & Mali & 1972 & Sim & 35.2 & \\
\hline França & Tunísia & 1973 & Sim & 38.2 & \\
\hline França & Benin & 1975 & Sim & 35 & \\
\hline França & Nova Caledônia & 1983 & Sim & 21.1 & \\
\hline França & $\begin{array}{l}\text { Saint-Pierre e } \\
\text { Miquelon }\end{array}$ & 1988 & Sim & 21.1 & \\
\hline
\end{tabular}

ANEXo II: Acordos que contêm cláusulas de reorganizações societárias relacionadas a empresas que desenvolvem atividades imobiliárias

\begin{tabular}{|c|c|c|c|c|c|}
\hline $\begin{array}{c}\text { Estado } \\
\text { Contratante 1 }\end{array}$ & $\begin{array}{c}\text { Estado } \\
\text { Contratante } 2\end{array}$ & $\begin{array}{c}\text { Ano de } \\
\text { Assinatura }\end{array}$ & Vigente? & Artigo & Observações \\
\hline França & Luxemburgo & 1958 & Sim & $\begin{array}{c}3 \\
\text { (Disposições Gerais) }\end{array}$ & $\begin{array}{l}\text { Texto incluído em } \\
5.9 .2014 \text {, vigente a } \\
\text { partir de 1.1.2017 }\end{array}$ \\
\hline Suíça & Coreia do Sul & 1980 & Sim & $\begin{array}{c}13.3 \text { (b) } \\
\text { (Ganhos de capital) }\end{array}$ & $\begin{array}{l}\text { Incluído pelo } \\
\text { Protocolo de } 2010 \\
\end{array}$ \\
\hline Luxemburgo & Rússia & 1993 & Sim & $\begin{array}{c}13.5 \text { (a) } \\
(\text { Ganhos de capital) }\end{array}$ & $\begin{array}{l}\text { Incluído pelo } \\
\text { Protocolo de } 2011\end{array}$ \\
\hline Países Baixos & Vietnã & 1995 & Sim & $\begin{array}{c}13.4 \\
\text { (Ganhos de capital) }\end{array}$ & --- \\
\hline Bélgica & Vietnã & 1996 & Sim & $\begin{array}{c}13.4 \\
\text { (Ganhos de capital) } \\
\end{array}$ & --- \\
\hline Chipre & Rússia & 1998 & Sim & $\begin{array}{c}13.5 \\
\text { (Ganhos de capital) }\end{array}$ & $\begin{array}{l}\text { Incluído pelo } \\
\text { Protocolo de } 2010\end{array}$ \\
\hline Países Baixos & Taiwan & 2001 & Sim & $\begin{array}{c}13.2 \\
\text { (Ganhos de capital) }\end{array}$ & --- \\
\hline Hong Kong & Bélgica & 2003 & Sim & $\begin{array}{c}13.4 \\
\text { (Ganhos de capital) }\end{array}$ & --- \\
\hline Bélgica & Azerbaijão & 2004 & Sim & $\begin{array}{c}13.2 \\
\text { (Ganhos de capital) }\end{array}$ & $\begin{array}{l}\text { Referência apenas } \\
\text { no Protocolo (it. 4) }\end{array}$ \\
\hline Países Baixos & Eslovênia & 2004 & Sim & $\begin{array}{c}13.4 \\
\text { (Ganhos de capital) } \\
\end{array}$ & --- \\
\hline Bélgica & Congo & 2007 & Sim & $\begin{array}{c}13.4 \\
\text { (Ganhos de capital) }\end{array}$ & --- \\
\hline Bélgica & Ruanda & 2007 & Sim & $\begin{array}{c}14.4 \\
\text { (Ganhos de capital) }\end{array}$ & --- \\
\hline Hong Kong & Luxemburgo & 2007 & Sim & $\begin{array}{c}13.4 \\
\text { (Ganhos de capital) }\end{array}$ & --- \\
\hline
\end{tabular}




\begin{tabular}{|c|c|c|c|c|c|}
\hline $\begin{array}{c}\text { Estado } \\
\text { Contratante 1 }\end{array}$ & $\begin{array}{c}\text { Estado } \\
\text { Contratante 2 }\end{array}$ & $\begin{array}{c}\text { Ano de } \\
\text { Assinatura }\end{array}$ & Vigente? & Artigo & Observações \\
\hline Suíça & Taiwan & 2007 & Sim & $\begin{array}{c}13.4 \text { (b) } \\
\text { (Ganhos de capital) }\end{array}$ & --- \\
\hline Bélgica & Moldávia & 2008 & Pendente & $\begin{array}{c}13.4 \\
\text { (Ganhos de capital) }\end{array}$ & $\begin{array}{l}\text { Acordo pendente } \\
\text { de ratificação }\end{array}$ \\
\hline Países Baixos & Gana & 2008 & Sim & $\begin{array}{c}13.4 \\
\text { (Ganhos de capital) }\end{array}$ & $\begin{array}{l}\text { Referência apenas } \\
\text { no Protocolo (it. XII) }\end{array}$ \\
\hline Países Baixos & Azerbaijão & 2008 & Sim & $\begin{array}{c}13.2 \\
\text { (Ganhos de capital) }\end{array}$ & --- \\
\hline Países Baixos & Reino Unido & 2008 & Sim & $\begin{array}{c}13.4 \text { (b) } \\
\text { (Ganhos de capital) }\end{array}$ & --- \\
\hline Hong Kong & Áustria & 2010 & Sim & $\begin{array}{c}13.4 \\
\text { (Ganhos de capital) }\end{array}$ & --- \\
\hline Hong Kong & Brunei & 2010 & Sim & $\begin{array}{c}14.4 \\
\text { (Ganhos de capital) }\end{array}$ & --- \\
\hline Hong Kong & França & 2010 & Sim & $\begin{array}{c}13.1 \text { (b) } \\
\text { (Ganhos de capital) }\end{array}$ & $\begin{array}{ll}\text { Também } & \text { há } \\
\text { referências } & \text { no } \\
\text { Protocolo } & \\
\end{array}$ \\
\hline Hong Kong & Hungria & 2010 & Sim & $\begin{array}{c}13.4 \\
\text { (Ganhos de capital) }\end{array}$ & --- \\
\hline Hong Kong & Indonésia & 2010 & Sim & $\begin{array}{c}13.4 \\
\text { (Ganhos de capital) }\end{array}$ & --- \\
\hline Hong Kong & Irlanda & 2010 & Sim & $\begin{array}{c}13.4 \\
\text { (Ganhos de capital) }\end{array}$ & $\begin{array}{l}\text { Referência apenas } \\
\text { no Protocolo (it. 3) }\end{array}$ \\
\hline Países Baixos & Panamá & 2010 & Sim & $\begin{array}{c}13.6(\mathrm{~b}) \\
\text { (Ganhos de capital) }\end{array}$ & --- \\
\hline Hong Kong & Kuwait & 2010 & Sim & $\begin{array}{c}13.4 \\
\text { (Ganhos de capital) }\end{array}$ & --- \\
\hline Hong Kong & Liechtenstein & 2010 & Sim & $\begin{array}{c}13.4 \\
\text { (Ganhos de capital) }\end{array}$ & --- \\
\hline Hong Kong & Nova Zelândia & 2010 & Sim & $\begin{array}{c}13.4 \\
\text { (Ganhos de capital) }\end{array}$ & --- \\
\hline Hong Kong & Países Baixos & 2010 & Sim & $\begin{array}{c}13.4 \\
\text { (Ganhos de capital) }\end{array}$ & --- \\
\hline Hong Kong & Reino Unido & 2010 & Sim & $\begin{array}{c}13.4 \\
\text { (Ganhos de capital) }\end{array}$ & --- \\
\hline Hong Kong & Suíça & $\begin{array}{l}2010 \\
2011 \\
\end{array}$ & $\begin{array}{l}\text { Não } \\
\text { Sim }\end{array}$ & $\begin{array}{c}13.4 \\
\text { (Ganhos de capital) }\end{array}$ & --- \\
\hline Luxemburgo & Panamá & 2010 & Sim & $\begin{array}{c}13.4 \\
\text { (Ganhos de capital) }\end{array}$ & --- \\
\hline Suíça & Uruguai & 2010 & Sim & $\begin{array}{c}13.4 \text { (b) } \\
\text { (Ganhos de capital) }\end{array}$ & --- \\
\hline Hong Kong & República Tcheca & 2011 & Sim & $\begin{array}{c}13.4 \\
\text { (Ganhos de capital) }\end{array}$ & --- \\
\hline
\end{tabular}




\begin{tabular}{|c|c|c|c|c|c|}
\hline $\begin{array}{c}\text { Estado } \\
\text { Contratante 1 }\end{array}$ & $\begin{array}{c}\text { Estado } \\
\text { Contratante 2 }\end{array}$ & $\begin{array}{c}\text { Ano de } \\
\text { Assinatura }\end{array}$ & Vigente? & Artigo & Observações \\
\hline Países Baixos & Alemanha & 2012 & Sim & $\begin{array}{c}13.2(b) \\
\text { (Ganhos de capital) }\end{array}$ & --- \\
\hline Hong Kong & Jersey & 2012 & Sim & $\begin{array}{c}13.4 \\
\text { (Ganhos de capital) }\end{array}$ & --- \\
\hline Hong Kong & Malásia & 2012 & Sim & $\begin{array}{c}14.4 \text { (b) } \\
\text { (Ganhos de capital) }\end{array}$ & --- \\
\hline Hong Kong & México & 2012 & Sim & $\begin{array}{c}13.4 \\
\text { (Ganhos de capital) }\end{array}$ & --- \\
\hline Chipre & Ucrânia & 2012 & Sim & $\begin{array}{c}13.5 \text { (b) (ii) } \\
\text { (Ganhos de capital) }\end{array}$ & $\begin{array}{l}\text { Incluído pelo } \\
\text { Protocolo de } 2015\end{array}$ \\
\hline Países Baixos & Etiópia & 2013 & Pendente & $\begin{array}{c}13.3 \\
\text { (Ganhos de capital) }\end{array}$ & $\begin{array}{l}\text { Acordo pendente } \\
\text { de ratificação }\end{array}$ \\
\hline Hong Kong & Guernsey & 2013 & Sim & $\begin{array}{c}13.4 \\
\text { (Ganhos de capital) }\end{array}$ & --- \\
\hline Hong Kong & Qatar & 2013 & Sim & $\begin{array}{c}13.4 \\
\text { (Ganhos de capital) }\end{array}$ & --- \\
\hline Bélgica & Uruguai & 2013 & Pendente & $\begin{array}{c}13.4 \\
\text { (Ganhos de capital) }\end{array}$ & $\begin{array}{l}\text { Há definições no } \\
\text { Protocolo } \\
\text { Acordo pendente } \\
\text { de ratificação }\end{array}$ \\
\hline Luxemburgo & Sri Lanka & 2013 & Sim & $\begin{array}{c}13.3 \\
\text { (Ganhos de capital) }\end{array}$ & --- \\
\hline Hong Kong & $\begin{array}{c}\text { Emirados Árabes } \\
\text { Unidos }\end{array}$ & 2014 & Sim & $\begin{array}{c}13.4 \\
\text { (Ganhos de capital) }\end{array}$ & --- \\
\hline Suíça & Chipre & 2014 & Sim & $\begin{array}{c}13.4(\mathrm{c}) \\
\text { (Ganhos de capital) }\end{array}$ & $\begin{array}{l}\text { Há definições no } \\
\text { Protocolo }\end{array}$ \\
\hline Luxemburgo & Croácia & 2014 & Sim & $\begin{array}{c}13.4 \\
\text { (Ganhos de capital) }\end{array}$ & --- \\
\hline Luxemburgo & Uruguai & 2015 & Pendente & $\begin{array}{c}13.4 \\
\text { (Ganhos de capital) }\end{array}$ & $\begin{array}{l}\text { Há definições no } \\
\text { Protocolo } \\
\text { Acordo pendente } \\
\text { de ratificação }\end{array}$ \\
\hline Países Baixos & Malawi & 2015 & Pendente & $\begin{array}{c}13.4(\mathrm{~d}) \\
\text { (Ganhos de capital) }\end{array}$ & $\begin{array}{l}\text { Acordo pendente } \\
\text { de ratificação }\end{array}$ \\
\hline Hong Kong & Rússia & 2016 & Pendente & $\begin{array}{c}13.4 \\
\text { (Ganhos de capital) }\end{array}$ & $\begin{array}{l}\text { Acordo pendente } \\
\text { de ratificação }\end{array}$ \\
\hline Hong Kong & Letônia & 2016 & Pendente & $\begin{array}{c}13.4 \\
\text { (Ganhos de capital) }\end{array}$ & $\begin{array}{l}\text { Acordo pendente } \\
\text { de ratificação }\end{array}$ \\
\hline Luxemburgo & Senegal & 2016 & Pendente & $\begin{array}{c}13.4(\mathrm{~b}) \\
\text { (Ganhos de capital) }\end{array}$ & $\begin{array}{l}\text { Acordo pendente } \\
\text { de ratificação }\end{array}$ \\
\hline
\end{tabular}


ANEXO III: Acordos que contêm cláusulas de reorganizações societárias para participações societárias específicas

\begin{tabular}{|c|c|c|c|c|c|}
\hline $\begin{array}{c}\text { Estado } \\
\text { Contratante 1 }\end{array}$ & $\begin{array}{c}\text { Estado } \\
\text { Contratante 2 }\end{array}$ & $\begin{array}{c}\text { Ano de } \\
\text { Assinatura }\end{array}$ & Vigente? & Artigo & Observações \\
\hline \multirow{3}{*}{ França } & \multirow{3}{*}{ Canadá } & 1975 & Sim & $\begin{array}{c}13.4 \\
\text { (Ganhos de capital) }\end{array}$ & --- \\
\hline & & 1987 & Sim & 5.3 & \multirow{2}{*}{$\begin{array}{l}\text { Protocolos à } \\
\text { Convenção }\end{array}$} \\
\hline & & 1995 & Sim & 10 & \\
\hline Estados Unidos & Israel & 1975 & Sim & $\begin{array}{c}15.1(\mathrm{e}) \\
\text { (Ganhos de capital) }\end{array}$ & $\begin{array}{l}\text { Texto incluído } \\
\text { pelo Protocolo de } \\
1993 \text { (item X.3) }\end{array}$ \\
\hline Países Baixos & Índia & 1988 & Sim & $\begin{array}{c}13.5 \\
\text { (Ganhos de capital) }\end{array}$ & --- \\
\hline Estados Unidos & Espanha & 1990 & Sim & $\begin{array}{c}13.4 \\
\text { (Ganhos de capital) }\end{array}$ & $\begin{array}{l}\text { Referência apenas } \\
\text { no Protocolo (it. 10) }\end{array}$ \\
\hline França & Suécia & 1990 & Sim & $\begin{array}{c}13.3 \\
\text { (Ganhos de capital) }\end{array}$ & $\begin{array}{l}\text { Referência apenas } \\
\text { no Protocolo (it. 1) }\end{array}$ \\
\hline Países Baixos & Nigéria & 1991 & Sim & $\begin{array}{c}13.4 \\
\text { (Ganhos de capital) }\end{array}$ & $\begin{array}{l}\text { Há definições no } \\
\text { Protocolo (it. VI) }\end{array}$ \\
\hline Estados Unidos & México & 1992 & Sim & $\begin{array}{c}13.4 \\
\text { (Ganhos de capital) }\end{array}$ & $\begin{array}{l}\text { Referência apenas } \\
\text { no Protocolo (it. 13) }\end{array}$ \\
\hline França & Áustria & 1993 & Sim & $\begin{array}{c}13.3 \text { (a) / (b) } \\
\text { (Ganhos de capital) }\end{array}$ & --- \\
\hline México & Países Baixos & 1993 & Sim & $\begin{array}{c}13.4 \\
\text { (Ganhos de capital) }\end{array}$ & $\begin{array}{l}\text { Suprimido pelo } \\
\text { Protocolo de } 2008\end{array}$ \\
\hline México & Suíça & 1993 & Sim & $\begin{array}{c}13.7 \\
\text { (Ganhos de capital) }\end{array}$ & $\begin{array}{l}\text { Incluído pelo } \\
\text { Protocolo de } 2009 \\
\end{array}$ \\
\hline França & Espanha & 1995 & Sim & $\begin{array}{c}13.2 \text { (b) } \\
\text { (Ganhos de capital) }\end{array}$ & --- \\
\hline França & Israel & 1995 & Sim & $\begin{array}{c}13.2(\mathrm{c}) \\
\text { (Ganhos de capital) }\end{array}$ & --- \\
\hline França & Japão & 1995 & Sim & $\begin{array}{c}13.2(\mathrm{c}) \\
(\text { Ganhos de capital) }\end{array}$ & --- \\
\hline Áustria & Estados Unidos & 1996 & Sim & $\begin{array}{c}13.7 \\
\text { (Ganhos de capital) }\end{array}$ & $\begin{array}{l}\text { Limitou tributação } \\
\text { apenas à Áustria } \\
\text { até } 2010\end{array}$ \\
\hline Bélgica & Cazaquistão & 1998 & Sim & $\begin{array}{c}13.2 \\
\text { (Ganhos de capital) }\end{array}$ & $\begin{array}{l}\text { Referência apenas } \\
\text { no Protocolo (it. 8) }\end{array}$ \\
\hline México & Irlanda & 1998 & Sim & $\begin{array}{c}13.3 \\
\text { (Ganhos de capital) }\end{array}$ & --- \\
\hline Luxemburgo & México & 2001 & Sim & $\begin{array}{c}13.2 \\
\text { (Ganhos de capital) }\end{array}$ & --- \\
\hline
\end{tabular}




\begin{tabular}{|c|c|c|c|c|c|}
\hline $\begin{array}{c}\text { Estado } \\
\text { Contratante } 1\end{array}$ & $\begin{array}{c}\text { Estado } \\
\text { Contratante 2 }\end{array}$ & $\begin{array}{c}\text { Ano de } \\
\text { Assinatura }\end{array}$ & Vigente? & Artigo & Observações \\
\hline Bélgica & Tunísia & 2004 & Sim & $\begin{array}{c}13.4 \\
\text { (Ganhos de capital) }\end{array}$ & --- \\
\hline Japão & Reino Unido & 2006 & Sim & $\begin{array}{c}13.3 \\
\text { (Ganhos de capital) }\end{array}$ & $\begin{array}{l}\text { Referência apenas } \\
\text { em Troca de Notas }\end{array}$ \\
\hline Japão & Austrália & 2008 & Sim & $\begin{array}{c}13.3 \\
\text { (Ganhos de capital) }\end{array}$ & $\begin{array}{l}\text { Referência apenas } \\
\text { no Protocolo (it. 18) }\end{array}$ \\
\hline Países Baixos & Arábia Saudita & 2008 & Sim & $\begin{array}{c}13.3 \text { e } 13.4 \\
\text { (Ganhos de capital) }\end{array}$ & $\begin{array}{l}\text { Renegociado em } \\
2008\end{array}$ \\
\hline México & Letônia & 2012 & Sim & $\begin{array}{c}13.7 \\
\text { (Ganhos de capital) }\end{array}$ & --- \\
\hline México & Malta & 2012 & Sim & $\begin{array}{c}13.3 \\
\text { (Ganhos de capital) }\end{array}$ & $\begin{array}{l}\text { Referência apenas } \\
\text { no Protocolo (it. 2) }\end{array}$ \\
\hline Irlanda & Ucrânia & 2013 & Sim & $\begin{array}{c}13.3 \\
\text { (Ganhos de capital) }\end{array}$ & --- \\
\hline França & Colômbia & 2015 & Pendente & $\begin{array}{c}13.4 \\
\text { (Ganhos de capital) }\end{array}$ & $\begin{array}{l}\text { Acordo pendente } \\
\text { de ratificação }\end{array}$ \\
\hline
\end{tabular}

ANEXo IV: Acordos que contêm cláusulas de reorganizações societárias abrangentes

\begin{tabular}{|c|c|c|c|c|c|}
\hline $\begin{array}{c}\text { Estado } \\
\text { Contratante 1 }\end{array}$ & $\begin{array}{c}\text { Estado } \\
\text { Contratante 2 }\end{array}$ & $\begin{array}{c}\text { Ano de } \\
\text { Assinatura }\end{array}$ & Vigente? & Artigo & Observações \\
\hline França & Bélgica & 1964 & Sim & $\begin{array}{c}15.8 \\
\text { (Rendimentos de } \\
\text { participações) }\end{array}$ & $\begin{array}{l}\text { Originalmente, } \\
\text { cláusula } 15.6\end{array}$ \\
\hline Alemanha & Suíça & 1971 & Sim & $\begin{array}{c}13.5 \\
\text { (Ganhos de capital) }\end{array}$ & $\begin{array}{l}\text { Referência apenas } \\
\text { na Troca de Notas }\end{array}$ \\
\hline Suíça & Áustria & 1973 & Sim & --- & $\begin{array}{l}\text { Referência apenas } \\
\text { em procedimento } \\
\text { amigável }\end{array}$ \\
\hline Canadá & Estados Unidos & 1980 & Sim & $\begin{array}{c}13.8 \\
\text { (Ganhos de capital) }\end{array}$ & $\begin{array}{l}\text { Também há } \\
\text { referência no } \\
\text { Protocolo de } 1995\end{array}$ \\
\hline Canadá & Países Baixos & 1986 & Sim & $\begin{array}{c}13.6 \\
\text { (Ganhos de capital) }\end{array}$ & --- \\
\hline Países Baixos & Zimbábue & 1989 & Sim & $\begin{array}{l}\text { Protocolo (art. 13) } \\
\text { (Ganhos de capital) }\end{array}$ & $\begin{array}{l}\text { Referência apenas } \\
\text { no Protocolo }\end{array}$ \\
\hline Canadá & México & 1991 & Não & $\begin{array}{c}13.5 \\
\text { (Ganhos de capital) }\end{array}$ & $\begin{array}{l}\text { Novo acordo } \\
\text { celebrado em } \\
\text { 2006, mas cláusula } \\
\text { de reorganização } \\
\text { societária }\end{array}$ \\
\hline Argentina & Espanha & 1992 & Não & 13 & Referência apenas \\
\hline
\end{tabular}




\begin{tabular}{|c|c|c|c|c|c|}
\hline $\begin{array}{c}\text { Estado } \\
\text { Contratante 1 }\end{array}$ & $\begin{array}{c}\text { Estado } \\
\text { Contratante 2 }\end{array}$ & $\begin{array}{c}\text { Ano de } \\
\text { Assinatura }\end{array}$ & Vigente? & Artigo & Observações \\
\hline & & 2013 & Sim & (Ganhos de capital) & no Protocolo (it. 5) \\
\hline México & Espanha & 1992 & Sim & $\begin{array}{l}\text { Protocolo (art. 13) } \\
\text { (Ganhos de capital) }\end{array}$ & $\begin{array}{l}\text { Referência apenas } \\
\text { no Protocolo (it. 8) }\end{array}$ \\
\hline Países Baixos & Estados Unidos & 1992 & Sim & $\begin{array}{c}14.8 \\
\text { (Ganhos de capital) }\end{array}$ & $\begin{array}{l}\text { Há também regras } \\
\text { no Protocolo }\end{array}$ \\
\hline Canadá & Hungria & 1992 & Sim & $\begin{array}{c}13.5 \\
\text { (Ganhos de capital) }\end{array}$ & --- \\
\hline Canadá & Zimbábue & 1992 & Sim & $\begin{array}{c}14.6 \\
\text { (Ganhos de capital) }\end{array}$ & --- \\
\hline Estados Unidos & Portugal & 1994 & Sim & $\begin{array}{c}14.3 \\
\text { (Ganhos de capital) }\end{array}$ & $\begin{array}{l}\text { Referência apenas } \\
\text { no Protocolo (it. 12) }\end{array}$ \\
\hline Canadá & Estônia & 1995 & Sim & $\begin{array}{c}13.5 \\
\text { (Ganhos de capital) }\end{array}$ & --- \\
\hline Canadá & Letônia & 1995 & Sim & $\begin{array}{c}13.5 \\
\text { (Ganhos de capital) }\end{array}$ & --- \\
\hline Canadá & Tanzânia & 1995 & Sim & $\begin{array}{c}13.6 \\
\text { (Ganhos de capital) }\end{array}$ & --- \\
\hline Canadá & Lituânia & 1996 & Sim & $\begin{array}{c}13.5 \\
\text { (Ganhos de capital) }\end{array}$ & --- \\
\hline Argentina & Países Baixos & 1996 & Sim & $\begin{array}{c}14 \\
\text { (Ganhos de capital) }\end{array}$ & $\begin{array}{l}\text { Referência apenas } \\
\text { no Protocolo (it. IX) }\end{array}$ \\
\hline Estados Unidos & Suíça & 1996 & Sim & $\begin{array}{c}13.6 \\
\text { (Ganhos de capital) }\end{array}$ & --- \\
\hline Canadá & Islândia & 1997 & Sim & $\begin{array}{c}13.5 \\
\text { (Ganhos de capital) }\end{array}$ & --- \\
\hline Canadá & Suíça & 1997 & Sim & $\begin{array}{c}13.5 \\
\text { (Ganhos de capital) }\end{array}$ & --- \\
\hline Canadá & Luxemburgo & 1999 & Sim & $\begin{array}{c}13.6 \\
\text { (Ganhos de capital) }\end{array}$ & --- \\
\hline Estados Unidos & Dinamarca & 1999 & Sim & $\begin{array}{c}13.8 \\
\text { (Ganhos de capital) }\end{array}$ & --- \\
\hline Canadá & Alemanha & 2001 & Sim & $\begin{array}{c}13.5 \\
\text { (Ganhos de capital) }\end{array}$ & --- \\
\hline Canadá & Peru & 2001 & Sim & $\begin{array}{c}13.5 \\
\text { (Ganhos de capital) }\end{array}$ & --- \\
\hline Canadá & Venezuela & 2001 & Sim & $\begin{array}{c}13.8 \\
\text { (Ganhos de capital) }\end{array}$ & --- \\
\hline Canadá & Itália & 2002 & Sim & $\begin{array}{c}13.5 \\
\text { (Ganhos de capital) }\end{array}$ & --- \\
\hline Canadá & Mongólia & 2002 & Sim & $\begin{array}{c}13.5 \\
\text { (Ganhos de capital) }\end{array}$ & --- \\
\hline Canadá & Noruega & 2002 & Sim & $\begin{array}{c}13.9 \\
\text { (Ganhos de capital) }\end{array}$ & --- \\
\hline
\end{tabular}




\begin{tabular}{|c|c|c|c|c|c|}
\hline $\begin{array}{c}\text { Estado } \\
\text { Contratante 1 }\end{array}$ & $\begin{array}{c}\text { Estado } \\
\text { Contratante 2 }\end{array}$ & $\begin{array}{c}\text { Ano de } \\
\text { Assinatura }\end{array}$ & Vigente? & Artigo & Observações \\
\hline Canadá & Coreia do Sul & 2006 & Sim & $\begin{array}{c}13.9 \\
\text { (Ganhos de capital) }\end{array}$ & --- \\
\hline Canadá & Finlândia & 2006 & Sim & $\begin{array}{c}13.6 \\
\text { (Ganhos de capital) }\end{array}$ & --- \\
\hline Alemanha & Liechtenstein & 2011 & Sim & $\begin{array}{c}13 \\
\text { (Ganhos de capital) }\end{array}$ & $\begin{array}{l}\text { Referência apenas } \\
\text { no Protocolo (it. 2) }\end{array}$ \\
\hline Alemanha & Turquia & 2011 & Sim & $\begin{array}{c}13 \\
\text { (Ganhos de capital) }\end{array}$ & $\begin{array}{l}\text { Referência apenas } \\
\text { no Protocolo (it. 5) }\end{array}$ \\
\hline Alemanha & Luxemburgo & 2012 & Sim & $\begin{array}{c}13 \\
\text { (Ganhos de capital) }\end{array}$ & $\begin{array}{l}\text { Referência apenas } \\
\text { no Protocolo (it. 3) }\end{array}$ \\
\hline Argentina & Chile & 2015 & Pendente & $\begin{array}{c}13 \\
\text { (Ganhos de capital) }\end{array}$ & $\begin{array}{l}\text { Referência apenas } \\
\text { no Protocolo (it. 14) } \\
\text { / Acordo pendente } \\
\text { de ratificação }\end{array}$ \\
\hline
\end{tabular}

ANEXo V: Avaliações estatísticas quanto à adoção, status e recorrência das cláusulas de reorganização societária



Distribuição Geográfica dos Acordos com Cláusula de Reorganização (por continente)

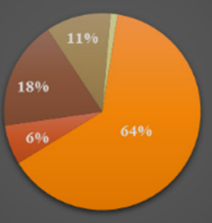

-Europa - América -Ásia $\approx$ África $=$ Oceania

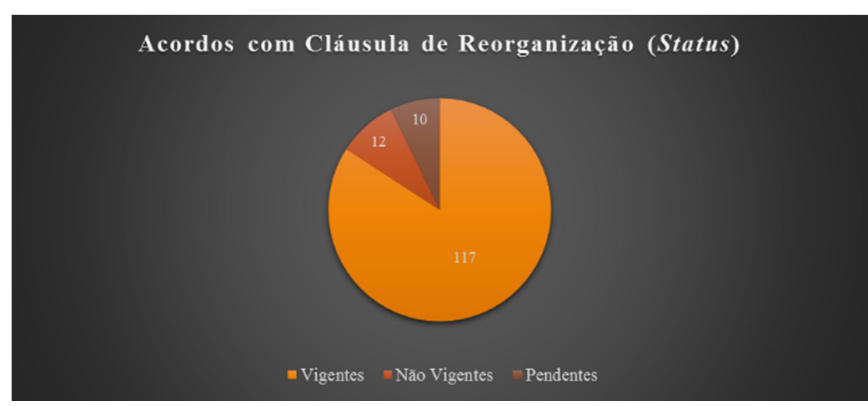

Gráfico 1 Países que mais celebraram acordos com cláusulas de reorganização societária

Gráfico 2 Distribuição geográfica dos acordos com cláusulas de reorganização societária

Gráfico 3 Status atual (vigência) dos acordos com cláusulas de reorganização societária 

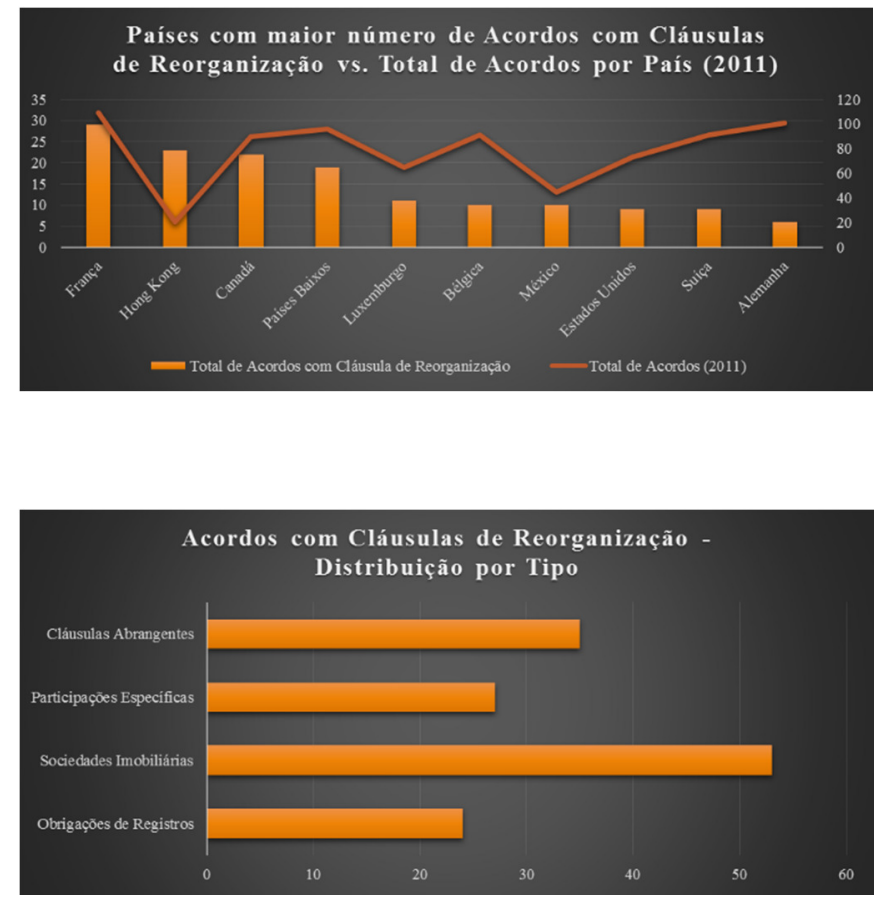

Gráfico 4 Relação entre número de acordos com cláusulas de reorganização societária e total de acordos celebrado pelo país (dados consolidados até 2011)

Gráfico 5 Distribuição do número de acordos com cláusulas de reorganização por grupo identificado nos Anexos I a IV, acima 


\section{BIBLIOGRAFIA}

ACCIOLY, Hildebrando. Manual de Direito Internacional Público. 16a Ed. São Paulo: Saraiva, 2008. AHN, Soo-Jeong, et. al. Taxation Aspects of Mergers and Acquisitions. Asia-Pacific Tax Bulletin. Set/Oct 2011.

ALEXY, Robert. Theorie der Grundrechte. 2. Aufl., Frankfurt am Main: Suhrkamp, 1994.

ALMEIDA, André; RAMSAY, Jase. A Ascensão das Multinacionais Brasileiras: $O$ Grande Salto de Pesos-Pesados Regionais a Verdadeiras Multinacionais. Rio de Janeiro: Elsevier/Campus, 2009.

AMARO, Luciano da Silva. Imposto sobre a Renda e Proventos de Qualquer Natureza. MARTINS, Ives Gandra da Silva (coord.). O Fato Gerador do Imposto sobre a Renda e Proventos de Qualquer Natureza. São Paulo: Resenha Tributária / CEEU, 1986.

Planejamento Tributário (Limites da Economia Fiscal - Planejamento Tributário). Revista de Direito Tributário ${ }^{\circ} 71.1998$.

ANAN JUNIOR, Pedro. Fusão, Cisão e Incorporação de Sociedades: Teoria e Prática. $3^{\text {a }}$ ed. São Paulo: Quartier Latin, 2009.

Planejamento Fiscal: Aspectos Teóricos e Práticos. São Paulo: Quartier Latin, 2009.

ANDRADE FILHO, Edmar Oliveira. Imposto de Renda das Empresas. 10ª ed. São Paulo: Atlas, 2013. Transparência Fiscal e Planejamento Tributário Internacional. MOREIRA JÚNIOR, Gilberto de Castro; PEIXOTO, Marcelo Magalhães. (orgs.). Direito Tributário Internacional. São Paulo: MP Editora, 2006.

ANTONIO, Renata Colafemina; BERTOLETTI, Isabel A. O Planejamento Fiscal Possível. ANAN Jr., Pedro. (Coord.) Planejamento Fiscal: Um Embate entre Princípios Constitucionais Tributários. São Paulo: Quartier Latin, 2005.

ARCE, Alex Córdova. El Regímen Fiscal de las Fusiones y Aquisiciones de Empresas. XXV Jornadas Latinoamericanas de Derecho Tributario. Fusiones y Aquisiciones: Aspectos Internacionales. Buenos Aires: Editorial Adeledo Perrot, 2010. Disponível em http://www.ipdt.org/editor/docs/01_Rev49_ACA.pdf. Acesso em 29.7.2016.

ARNOLD, Brian J.; HARRIS, Neil H. NAFTA and the taxation of corporate investment: a view from within NAFTA. Tax Law Review n 49. New York: Univ. School of Law, 1994.

; SASSEVILLE, Jacques; ZOLT, Eric. Summary of the Proceedings of an Invitational Seminar on Tax Treaties in the 21st Century. Canadian Tax Journal no 50. 2002. Disponível em http://scholarship.law.cornell.edu/cgi/viewcontent.cgi?article=1568\&context=facpub. Acesso em 8.10.2016.

ASCARELLI, Tulio et. al. Lucros Extraordinários e Imposto de Renda. São Paulo: Livraria Martins Editora, 1944. 
ASOREY, Rubén O., Reorganizaciones Empresariales. Aspectos societarios, fiscales, antimonopólicos, e internacionales. Buenos Aires: La Ley, 1996.

ASSEIS, Pedro A. A. Abujamra. O Ajuste a Valor Justo (AVJ) Analisado sob o Conceito Jurídico de Renda. Revista Direito Tributário Atual n 32. São Paulo: Quartier Latin, 2014.

Apontamentos sobre os rendimentos decorrentes da prestação de serviços técnicos sem transferência de tecnologia, vis-à-vis as Convenções celebradas pelo Brasil para evitar a dupla tributação em matéria Imposto de Renda. Revista Fórum de Direito Tributário $\mathrm{n}^{\circ} 68$. Belo Horizonte: Editora Fórum, 2014.

LOPES JUNIOR, Jorge Ney de Figueiredo. A Adoção do IFRS no Direito Tributário Brasileiro e os Limites da Conciliação do Contábil com o Legal Tributário. MOSQUERA, Roberto Quiroga; LOPES, Alexsandro Broedel. (orgs.). Controvérsias Jurídico-Contábeis (Aproximações e Distanciamentos). vol. 6. São Paulo: Dialética, 2015.

. As Cláusulas de L.O.B. e o Combate ao Treaty Shopping. Revista Direito Tributário Atual $\mathrm{n}^{\circ}$ 33. São Paulo: IBDT/Dialética, 2015.

. Ação no 6 do BEPS e a Prevenção de “Abusos”: Análise Crítica. GOMES, Marcus Lívio; SCHOUERI, Luís Eduardo Schoueri (orgs.). A Tributação Internacional na Era Pós-BEPS: Soluções Globais e Peculiaridades de Países em Desenvolvimento. vol. 2. Rio de Janeiro: Lumen Iuris, 2016.

ATAÍDE JÚNIOR, Jaldemiro Rodrigues de. As tradições jurídicas de Civil Law e Common Law. FREIRE, Alexandre. et. al. Novas Tendências do Processo Civil: Estudos sobre o projeto do Novo Código de Processo Civil. v.1. Salvador: JusPodivm, 2013.

ATTARD, Edward, et. al. Triangular cases and double tax relief: A decision of the Netherlands Supreme Court. RUSSO, Raffaele; FONTANA, Renata (eds.). A Decade of Case Law: Essays in honour of the 10th anniversary of the Leiden Adv LLM in International Tax Law. Amsterdam: IBFD, 2008.

AULT, Hugh J. The Role of the OECD Commentaries in the Interpretation of Tax Treaties. VAN RAAD, Kees; ALPERT, Herbert H. (coords.). Essays on International Taxation. Boston: Kluwer, 1993. .; SASSEVILLE, Jacques. Taxation and Non-Discrimination: A Reconsideration. World Tax Journal $n^{\circ} 2.2010$.

ÁVILA, Humberto Bergmann. A distinção entre princípios e regras e a redefinição do dever de proporcionalidade. Revista de Direito Administrativo no 215. Rio de Janeiro: Editora Fórum, 1999. p. 151-179.

Teoria dos Princípios: Da definição à aplicação dos princípios jurídicos. $7^{\mathrm{a}}$ ed. São Paulo: Malheiros, 2007.

Conceito de Renda e Compensação de Prejuízos Fiscais. São Paulo: Malheiros, 2011.

AVI-YONAH, Reuven; LAHAV, Yaron. The Effective Tax Rate of the Largest US and EU Multinationals. University of Michigan Public Law Working Paper No. 255 Disponível em http://papers.ssrn.com/sol3/papers.cfm?abstract id=1949226. Acesso em 9.10.2016. 
AZEVEDO, Antônio Junqueira de. Negócio Jurídico: Existência, Validade e Eficácia. 4a ed. São Paulo: Saraiva, 2010.

BAKER, Paul L. An Analysis of Double Taxation Treaties and their Effect on Foreign Direct Investment. Estudo apresentado à Faculdade de Economia da Universidade de Cambridge. Disponível em http://www2.warwick.ac.uk/fac/soc/economics/events/seminars-schedule/conferences/peuk12/paul_1_baker_dtts_on fdi_23_may_2012.pdf. Acesso em 8.10.2016

BAKER, Phillip. Double Taxation Conventions and International Tax Law. London: Sweet \& Maxwell, 1994.

A Tributação Internacional no Século XXI. Revista Direito Tributário Atual no ${ }^{19}$. São Paulo: IBDT/Dialética, 2005.

BAMMENS, Niels; BROE, Luc De. Treaty Shopping and Avoidance of Abuse. LANG, Michael. et. al. (coords). Tax Treaties: Building Bridges between Law and Economics. Amsterdam: IBFD, 2010.

BARBOSA, Luiz Roberto Peroba; MARTONE, Rodrigo Corrêa. A importância dos precedentes dos tribunais e a insegurança jurídica do Sistema Tributário Nacional. Revista Dialética de Direito Tributário $\mathrm{n}^{\circ} 217$. out/2013.

BARRETO, Antonio; ROCHA, Ângela. A Expansão das Fronteiras: Brasileiros no Exterior. ROCHA, Ângela (Org.). As Novas Fronteiras: A Multinacionalização das Empresas Brasileiras. Rio de Janeiro: Mauad, 2003.

BARTHEL, Fabian. et. al. The Relationship between Double Taxation Treaties and Foreign Direct Investment. LANG, Michael. et. al. (coords). Tax Treaties: Building Bridges between Law and Economics. Amsterdam: IBFD, 2010.

BATISTA, Diego Alves Amaral. Silencing the Tower of Babel: A Proposed Solution to the Tax Treatment of Goodwill Across Borders. Special Report. Tax Management Transfer Pricing Report. vol. $22, \mathrm{n}^{\circ} 11$. Washington, D.C.: Bloomberg BNA, 2013.

BAXI, D.; Sanghvi, S. Taxability of Cross-Border Mergers and Acquisitions: The Vodafone Case. AsiaPacific Tax Bulletin vol. 15. 2009.

BETTI, Emilio. Teoria geral do negócio jurídico. Campinas: LZN, 2003.

BEUSCH, K.; THOMAS, J. The national and especially international tax problems arising from the merger of enterprises: General Report. Cahiers de droit fiscal international n ${ }^{\circ}$ 55b. 1970.

BIANCO, João Francisco. Transparência Fiscal Internacional. São Paulo: Dialética, 2007.

O Conceito de Valor Justo e seus Reflexos Tributários. MOSQUERA, Roberto Quiroga; LOPES, Alexsandro Broedel (coord.). Controvérsias Jurídico-Contábeis: Aproximações e Distanciamentos. vol. 5. São Paulo: Dialética, 2014.

Natureza Jurídica do resultado de avaliação do investimento relevante por equivalência patrimonial. Revista Direito Tributário Atual n² 20. São Paulo: Dialética, 2006. 
BIFANO, Elidie Palma. O Direito Tributário e a interdisciplinaridade com outros ramos do saber. Revista Direito Tributário Atual n 30. São Paulo: IBDT/Dialética, 2014.

O planejamento tributário internacional e as boas práticas de governança corporativa nas empresas. Revista de Direito Tributário Internacional. $n^{\circ}$ 05. fev. 2007. Reorganizações societárias e combinação de negócios: temas atuais. Revista Dialética de Direito Tributário $n^{\circ}$ 198. mar/2012. Investimentos Brasileiros no Exterior: Os Desafios Tributários das Multinacionais Brasileiras. TÔRRES, Heleno Taveira. Direito Tributário e Ordem Econômica: Homenagem aos 60 anos da ABDF. São Paulo: Quartier Latin, 2010.

BLACK, Henry Campbell. Black's Law Dictionary. 4ª ed. St. Paul: West Publishing Co., 1951.

BLESSING, Peter H. Tax Planning for International Mergers, Acquisitions, Joint Ventures and Restructurings. $2^{\mathrm{a}}$ ed. Alphen aan den Rijn: Wolters Kluwer, 2014.

BLOCK, Cheryl D. Corporate Taxation: Examples and Explanations. 3. ed. New York: Aspen Publishers, 2004.

BOIDMAN, Nathan; GLICKLICH, Peter A. LEITNER, Abraham. Selected Thoughts on the Pending Protocol to the U.S.-Canada Income Tax Treaty. Tax Management International Journal $\mathrm{n}^{\circ} 36.2007$. Disponível em https://www.dwpv.com/ /media/Files/PDF_EN/2014-2007/Publication__CrossBorder.ashx. Acesso em 15.12.2016.

BORGES, Antonio de Moura. Convenções sobre dupla tributação internacional entre Estados desenvolvidos e Estados em Desenvolvimento. Revista Dialética de Direito Tributário nº 8. São Paulo: Dialética, 1996.

Convenções sobre Dupla Tributação Internacional. Teresina: EDUFPI, 1992.

BORREGO, Félix Alberto Vega. Limitation on Benefits Clauses in Double Taxation Conventions. Eucotax Series on European Taxation. Alphen aan den Rijn: Kluwer Law International, 2006.

BOUCHER, Hércules. Estudos de Imposto de Renda e Lucros Imobiliários: Teoria e Prática. Rio de Janeiro: Freitas Bastos, 1953.

BOWMAN, Edward H.; SINGH, Harbir. Corporate Restructuring: Reconfiguring the Firm. Strategic Management Journal ${ }^{\circ} 14.1993$.

BOZZA, Fábio Piovesan. Planejamento Tributário e Autonomia Privada. São Paulo: IBDT / Quartier Latin, 2015.

BRAUNER, Yariv. Taxing Cross-Border M\&A in a Globalizing World. NYU Law School, Public Law Research Paper No. 63. Disponível em http://papers.ssrn.com/sol3/papers.cfm?abstract_id=410106. Acesso em 9.10.2016.

What the BEPS? Florida Tax Review vol $16 \mathrm{n}^{\circ}$ 2. Gainesville: University of Florida College of Law, 2014. 
BRODERSEN, Christian; MÜCKL, Norbert. The German Restructuring Privilege (Section 8c(1a) of the Corporate Income Tax Act) and the EU State Aid Rules (Article 107(1) of the TFEU). European Taxation. 2014. pp. 56-62.

BROE, Luc De. International Tax Planning and Prevention of Abuse: A Study under Domestic Tax Law, Tax Treaties and EC Law in Relation to Conduit and Base Companies. IBFD Doctoral Series vol. 14. Amsterdam: IBFD, 2008.

BROWN, Catherine; MANOLAKAS, Christine. Organizations, Reorganizations, Amalgamations, Divisions and Dissolutions: Cross-Border Assets, Double Taxation and Potential Relief under the U.S.Canada Tax Treaty. Georgia Journal of International and Comparative Law $\mathrm{n}^{\circ} 26$. Disponível em http://digitalcommons.law.uga.edu/gjicl/vol26/iss2/3. Acesso em 15.12.2016.

CALIENDO, Paulo. Princípio da Neutralidade Fiscal: Conceito e Aplicação. PIRES, Adilson Rodrigues; TÔRRES, Heleno Taveira (orgs.). Princípios de Direito Financeiro e Tributário: Estudos em Homenagem ao Professor Ricardo Lobo Torres. Rio de Janeiro: Renovar, 2006.

CANTO, Gilberto de Ulhôa. A Aquisição de Disponibilidade e o Acréscimo Patrimonial no Imposto de Renda. MARTINS, Ives Gandra da Silva (coord.). Estudos sobre o Imposto de Renda: Em Memória de Henry Tilbery. São Paulo: Editora Resenha Tributária, 1994.

Elisão e Evasão Fiscal. Caderno de Pesquisas Tributárias. Resenha Tributária. vol. 13, 1988.

CARVALHOSA, Modesto; EIZIRIK, Nelson. Estudos de Direito Empresarial. São Paulo: Saraiva, 2010. CASTRO, Leonardo Freitas de Moraes e. Caso Vodafone: Ganho de Capital de Não Residente Decorrente de Alienação Indireta de Participação Societária em Sociedade na Índia e Reflexões sobre Eventual Aplicabilidade no Brasil. CASTRO, Leonardo Freitas de Moraes e (coord.). Tributação Internacional: Análise de Casos. vol. 3. São Paulo: MP Editora, 2015.

Cláusulas de limitações de benefícios (LOB clauses): exame comparativo entre Modelo Norte-Americano de Tratados, Convenção Modelo da OCDE e acordos internacionais contra a bitributação celebrados pelo Brasil. Revista Fórum de Direito Tributário no 61. 2013.

CASTRO, Rodrigo R. Monteiro; ARAGÃO, Leandro Santos de (coords.). Reorganização Societária. São Paulo: IDSA / Quartier Latin, 2005.

CAVARZANI, Vinicius. O Common Law, o Civil Law e um a análise sobre a tradição jurídica brasileira.

Revista de Processo $n^{\circ} 231$. mai/2014.

CHANCELLOR, Thomas. Imputed Income and the Ideal Income Tax. CARON, Paul L. BURKE, Karen

C. McCOUCH, Grayson M.P. Federal Income Tax Anthology. Ohio: Anderson, 1997.

CLAUSING, Kimberly A. The Revenue Effects of Multinational Firm Income Shifting. Tax Notes, 2011. Multinational Tax Avoidance and Tax Policy. National Tax Journal n 57, 2009. 
CLOER, Adrian; VOGEL, Nina. Die Sanierungsklausel: Bestandsaufnahme und Handlungsempfehlungen. IWW Institut. Disponível em http://www.iww.de/pistb/schwerpunktthema/unionsrecht-die-sanierungsklauselbestandsaufnahme-und-handlungsempfehlungen-f40293. Acesso em 5.12.2016.

COELHO, Fábio Ulhôa. Curso de Direito Comercial. 10ª ed. São Paulo: Saraiva, 2009.

Comentários à nova Lei de Falências e Recuperação de Empresas. $8^{\mathrm{a}}$ ed. São Paulo: Saraiva, 2011.

COELHO, Sacha Calmon Navarro. Imposto sobre a Renda e Incorporação de Ações de Sociedade Holding. Revista Dialética de Direito Tributário nº 77. São Paulo: Dialética, 2002.

COLLINS, Julie; DEEN, Kemsley; LANG, Mark. Cross-Jurisdictional Income Shifting and Earnings Valuation. Journal of Accounting Research $\mathrm{n}^{\circ}$ 36. 1998. Disponível em http://public.kenanflagler.unc.edu/faculty/langm/Publications/Cross-Jurisdictional_Income_Shifting.pdf. Acesso em 9.10.2016.

COMPARATO, Fábio Konder. O Irredentismo da Nova Contabilidade e as Operações de Leasing. Revista de Direito Mercantil no 68. São Paulo: RT, 1987.

Segurança e Democracia. BOLIVAR, Lamounier; WEFFORT, Francisco C.; BENEVIDES, Maria Victoria. Direito, Cidadania e Participação. São Paulo: T. A. Queiroz, 1981.

Parecer. Revista Forense ${ }^{\circ}{ }^{278}$. Rio de Janeiro: Forense, 1982.

COSTA, Alcides Jorge. Conceito de Renda Tributável. MARTINS, Ives Gandra da Silva. (ccord). Estudos sobre o Imposto de Renda: Em Memória de Henry Tilbery. São Paulo: Editora Resenha Tributária, 1994. CUNHA, Fábio Lima. Os serviços sem Transferência de Tecnologia no Contexto dos Tratados para Evitar a Dupla Tributação da Renda. Revista Dialética de Direito Tributário nº 190. São Paulo, 2011.

CUNHA, Rodrigo Ferraz P. Reorganizações Societárias no Novo Código Civil. RODRIGUES, Frederico Viana. Direito de Empresa no Novo Código Civil. Rio de Janeiro: Forense, 2004.

CUNHA JUNIOR, José Roberto. Determinantes da Atratividade de Investimentos Estrangeiros Diretos no Brasil. São Paulo: 2012. Tese de Doutorado apresentada à Faculdade de Economia, Administração e Contabilidade da Universidade de São Paulo.

DE GOEDE, Jan J. P. Allocation of Taxing Rights on Income from Cross-Border (Indirect) Sale of Shares. Asia-Pacific Tax Bulletin vol 18. 2012.

DERZI, Mizabel de Abreu Machado. Direito Tributário, Direito Penal e Tipo. São Paulo: RT, 1988. Princípio de Cautela ou Não Paridade de Tratamento entre o Lucro e o Prejuízo. CARVALHO, Maria Augusta Machado de (coord.). Estudos de Direito Tributário em Homenagem à Memória de Gilberto de Ulhôa Canto. Rio de Janeiro: Forense, 1998.

DESAI, Mihir A.; FOLEY, C. Fritz; HINES JR., James R. Tax Policy and the Efficiency of U.S. Direct Investment Abroad. National Bureau of Economic Research Working Paper 17202. 2011. Disponível em http://www.nber.org/papers/w17202. Acesso em 7.12.2016. 
A Multinational Perspective on Capital Structure Choice and Internal Capital Markets. National Bureau of Economic Research Working Paper 9715. 2003. Disponível em http://www.nber.org/papers/w9715. Acesso em 7.12.2016.

DEVEREUX, Michael P. Taxation of outbound direct investment: Economic principles and tax policy considerations. Oxford University Centre for Business Taxation Working Paper WP 08/24. 2008. Disponível em http://www.sbs.ox.ac.uk/faculty-research/tax/publications/working-papers/taxation-outbound-directinvestment-economic-principles-and-tax-policy-considerations. Acesso em 7.12.2016.

DICKINSON, Keith. Financial Market Operations. West Sussex: John Wiley \& Sons, Ltd., 2015.

DISCHINGER, Matthias. Profit Shifting by Multinationals: Indirect Evidence from European Micro Data. Discussion Paper Ludwig-Maximilians-University Munich, 2010. Disponível em http://epub.ub.unimuenchen.de/2029/1/dischinger_2007_profit_shifting.pdf. Acesso em 9.10.2016.

.; RIEDEL, Nadine. The Role of Headquarters in Multinational Profit Shifting Strategies, International Tax and Public Finance. Munich Discussion Paper No. 2010-12. Ludwig-MaximiliansUniversity Munich, 2010. Disponível em http://epub.ub.uni-muenchen.de/11352/1/dischinger riedel 2010 HQs PS.pdf. Acesso em 9.10.2016.

DÓRIA, Antonio Roberto Sampaio. Elisão e Evasão Fiscal. 2a ed. São Paulo: Bushatsky, 1977.

DORNELLES, Francisco Neves. A dupla tributação internacional da renda. Rio de Janeiro: FGV, 1979. ECKER, Thomas. A VAT/GST Model Convention: Tax Treaties as Solution for Value Added Tax and Goods and Services Tax Double Conventions. Amsterdam: IBFD, 2013.

EIZIRIK, Nelson. Incorporação de Ações: Aspectos Polêmicos. WARDE JR., Walfrido Jorge (Coord.). Fusão, Cisão, Incorporação e Temas Correlatos. São Paulo: Quartier Latin, 2009.

ELÍAS, Enrique. Derecho Societario Peruano: La Ley General de Sociedades del Perú. vol. III. Lima: Editora Normas Legales, 1999.

ENDERS, Dieter; Spengel, Christoph. International Company Taxation and Tax Planning. Alphen aan den Rijn: Wolters Kluwer, 2015.

ENGELEN, Frank; DOUMA, Sjoerd. The Legal Status of the OECD Commentaries. Amsterdam: IBFD, 2008.

ENGLISCH, Joachim. Reform of the Reorganization Tax Act and Related Changes. European Taxation. 2007.

FERRARA, Francisco. A simulação dos negócios jurídicos. Campinas: Red Livros, 1999.

FERRAZ JR. Tercio Sampaio. Introdução ao Estudo do Direito: Técnica, Decisão, Dominação. $4^{\mathrm{a}}$ ed. São Paulo: Ed. Atlas, 2003.

FETT, Emily. Triangular Cases: The Application of Bilateral Income Tax Treaties in Multilateral Situations. Doctoral Series vol. 29. The Netherlands: IBFD, 2013. 
FONSECA, Alessandro Amadeu da. A Tributação da Renda e sua Correlação com os Princípios Contábeis Geralmente Aceitos. MOSQUERA, Roberto Quiroga; LOPES, Alexsandro Broedel (coord.). Controvérsias Jurídico-Contábeis: Aproximações e Distanciamentos. São Paulo: Dialética, 2010.

FREEDMAN, Judith. Treatment of Capital Gains and Losses. ESSERS, Peter; RIJKERS, Arie (cords.). The Notion of Income from Capital. Amsterdam: IBFD, 2005.

FUEST, Clemens; RIEDEL, Nadine. Tax Evasion and Tax Avoidance in Developing Countries: The Role of International Profit Shifting. Oxford University Centre for Business Taxation Working Paper WP 10/12. Disponível em http://www.sbs.ox.ac.uk/sites/default/files/Business_Taxation/Docs/Publications/Working Papers/Series_10/WP1012.pdf. Acesso em 9.10.2016.

GALHARDO, Luciana Rosanova. Rateio de Despesas no Direito Tributário. São Paulo: Quartier Latin, 2004.

Amortization of intangible assets in Brazil: Strategies and perspectives. Miami. 8th Annual

U.S. - Latin America Tax Planning Strategies, 2015.

Preços de Transferência e as Reorganizações Societárias. ROCHA, Valdir de Oliveira.

Grandes Questões Atuais do Direito Tributário. $8^{\circ}$ vol. São Paulo: Dialética, 2004. Serviços Técnicos Prestados por Empresa Francesa e Imposto de Renda na Fonte. Revista

Dialética de Direito Tributário no 31. São Paulo: Dialética, 1998.

GAMMIE, Malcolm; BALL, Susan. Tax on Company Reorganizations. $2^{\mathrm{a}}$ ed. [s.1.]: Taxation Publishing, 1982.

GARBARINO, Carlo. La Tassazione del Reddito Transnazionale. Pádua: Cedam, 1990.

Regime Fiscal das Reorganizações Internacionais e no Âmbito da União Europeia. Revista

Direito Tributário Atual n 31. São Paulo: IBDT / Dialética, 2014.

GARCIA, Ana Carolina Moreira; FONSECA, Frederico de Almeida. Não-incidência de IRRF sobre Remessas ao Exterior - Serviços Técnicos sem Transferência de Tecnologia - Análise de Jurisprudência.

Revista Dialética de Direito Tributário no 172. São Paulo: Dialética, 2010.

GARCIA BELSUNCE, Horacio. Doble imposición internacional. Temas de derecho tributario. Buenos Aires: Abeledo-Perrot, 1982

GARCÍA PRATS, Francisco Alfredo. Triangular Cases and Residence as a Basis for Alleviating International Double Taxation: Rethinking the Scope of Double Tax Treaties. Intertax n 11. 1994.

GARELLI, Alessandro. Il concetto di reddito nella scienza finanziaria. Milano: Società Editrice Libraria, 1917.

GIANNETTI, Leonardo Varella. A Tributação da remuneração de serviços de assistência técnica, sem transferência técnica, prestados por não-residentes em Estado com o qual o Brasil possua tratado para evitar a dupla tributação. Estudo de caso. Revista Tributária e de Finanças Públicas no 88. São Paulo: RT, 2009. 
GODBOLE, Prasad G. Mergers, Acquisitions and Corporate Restructuring. $2^{\text {a }}$ ed. New Delhi: Vikas Publishing House Pvt Ltd, 2013.

GOMI, Yuji; HONJO, Tasuku (eds.). 2015 Corporation Tax Act of Japan. Disponível em http://www.sozeishiryokan.or.jp/corporation_tax/z_pdf/corporation_tax2015.pdf\#page=208. Acesso em 30.7.2016. GONÇALVES, José Arthur Lima. Planejamento Tributário - Certezas e Incertezas. ROCHA, Valdir de Oliveira. (Coord) Grandes Questões Atuais do Direito Tributário. vol. 10. São Paulo: Dialética, 2006. GONZAGA, Livia Leite Baron. A Interpretação das Convenções contra Dupla Tributação Internacional à Luz da Teoria da Argumentação Jurídica. Tese de Doutorado apresentada à Faculdade de Direito da Universidade de São Paulo. 2010.

GRECO, Marco Aurélio. Planejamento Tributário. 3ª ed. São Paulo: Dialética, 2011. Planejamento Tributário: Nem tanto ao mar, nem tanto à terra. ROCHA, Valdir de Oliveira. (Coord) Grandes Questões Atuais do Direito Tributário. vol. 10. São Paulo: Dialética, 2006.

GRISI FILHO, Celso Cláudio de Hildebrand e. Contribuição ao estudo tributário sobre os investimentos internacionais. São Paulo: 2005. Dissertação de Mestrado apresentada à Faculdade de Direito da Universidade de São Paulo.

GRUBERT, Harry. Intangible Income, Intercompany Transactions, Income Shifting, and the Choice of Location. National Tax Journal $n^{\circ}$ 56. 2003. Disponível em http://ntj.tax.org/wwtax/ntjrec.nsf/A436689948 63D55985256D8D00754FD3/\$FILE/A06.pdf. Acesso em 9.10.2016

GRUPPENMACHER, Betina Treiger. O Princípio da Não Discriminação e os Tratados Internacionais em Matéria Tributária. SCHOUERI, Luís Eduardo et. al. (orgs.). Estudos de Direito Tributário em Homenagem ao Prof. Gerd Willi Rothmann. São Paulo: Quartier Latin, 2016.

GUERRA, José Calejo. Limitation on Benefits Clauses and EU Law. European Taxation. 2011.

GUERREIRO, José Alexandre Tavares. Sociedade anônima. Reorganização societária. Alienação de ações. Alienação de controle direta e indireta: inocorrência. Inaplicabilidade do art. 254-A da Lei das Sociedades Anônimas. Revista de Direito Bancário e do Mercado de Capitais. v. 12, n 45. jul./set. 2009. GUTIERREZ, Miguel Delgado. Planejamento Tributário: Elisão e Evasão Fiscal. São Paulo: Quartier Latin, 2006.

Da Renda Imputada. Revista Direito Tributário Atual n 23. São Paulo: Quartier Latin, 2009.

HARET, Florence Cronemberger. Planejamento tributário e a desconsideração do negócio jurídico: análise do parágrafo único do art. 116 do CTN à luz do direito positivo. Revista de Direito Tributário. São Paulo. vol. nº 99. 2008.

HERMAN, Doron. Taxing Portfolio Income in Global Financial Markets: A Positive and Normative Exploration of Possible Solutions. Doctoral Series 2. Amsterdam: IBFD, 2002. 
HINES JR, James R. Tax Policies and the Activities of Multinational Corporations. National Bureau of Economic Research Working Paper 5589. 1996. Disponível em http://www.nber.org/papers/w5589.pdf? new window=1. Acesso em 9.10.2016.

HOLMES, Kevin. The Concept of Income: A Multidisciplinary analysis. Doctoral Series vol. 1. The Netherlands: IBFD, 2000.

International Tax Policy and Double Tax Treaties. The Netherlands: IBFD, 2014.

HOORN JR., J. Van. Bitributação: Uma tentativa de definição. MACHADO, Brandão (org.). Direito tributário: Estudos em homenagem ao Prof. Ruy Barbosa Nogueira. São Paulo: Saraiva, 1984.

HUCK, Hermes Marcelo. Evasão e Elisão: Rotas Nacionais e Internacionais do Planejamento Tributário. São Paulo: Saraiva, 1997.

HUIZINGA, Harry; LAEVEN, Luc. International Profit Shifting within Multinationals: A Multi-Country Perspective. Journal of Public Economics $\mathrm{n}^{\circ}$ 92, 2009. pp. 1164-1182. Disponível em http://ec.europa.eu/economy finance/publications/publication590 en.pdf. Acesso em 9.10.2016.

HUNT, Peter A. Structuring Mergers \& Acquisitions: A Guide to Creating Shareholder Value. $2^{\mathrm{a}}$ ed. New York: Aspen Publishers, 2004.

IUDÍCIBUS, Sérgio de. et. al. Manual de Contabilidade Societária: Aplicável a todas as sociedades, de acordo com as normas internacionais e do CPC. FIPECAFI - Fundação Instituto de Pesquisas Contábeis, Atuariais e Financeiras. São Paulo: Ed. Atlas, 2010.

IFRS. Normas Internacionais de Relatório Financeiro. Parte A: A Estrutura Conceitual e Requisitos. São Paulo: IBRACON - Instituto dos Auditores Independentes do Brasil, 2013.

JHABAKH, P. Raj Kumar. Vodafone or Idea: Battle for the Taxes. Derivatives \& Financial Instruments vol. 13. 2011.

JIMÉNEZ, Adolfo J. Martín, et. al. Triangular Cases, Tax Treaties and EC Law: The Saint-Gobain Decision of the ECJ. Bulletin for International Taxation $n^{\circ}$ 55. Amsterdam: IBFD, 2001.

JONES, John F. Avery. Tax Treaty Interpretation in the United Kingdom. LANG, Michael. Tax Treaty Interpretation. Wien: Linde, 2001. Conflicts of Qualification: Comment on Prof. Vogel's and Alexander Rust's Articles. Tax

Treaty Monitor Bulletin. Maio/2003. Disponível em http://www.fd.unl.pt/docentes docs/ma/fsc MA 5975.PDF. Acesso em 7.12.2016.

The Interaction Between Tax Treaty Provisions and Domestic Law. MAISTO, Guglielmo. Tax Treaties and Domestic Law. Amsterdam: IBFD, 2006.

KANG, Nam-Hoon; JOHANSSON, Sara. Cross-Border Mergers and Acquisitions: Their Role in Industrial Globalisation, OECD Science, Technology and Industry Working Papers, No. 2000/01, OECD Publishing, Paris. 2000. Disponível em http://www.oecd-ilibrary.org/science-and-technology/cross-bordermergers-and-acquisitions_137157251088. 
KAVELAARS, Peter. Accrual versus Realization. ESSERS, Peter; RIJKERS, Arie (cords.). The Notion of Income from Capital. Amsterdam: IBFD, 2005.

KELSEN, Hans. Teoria Pura do Direito. $7^{\text {a }}$ ed. São Paulo: Martins Fontes, 2006.

KIRCHHOF, Paul. Der sanfte Verlust der Freiheit. München: Carl Hanser, 2004.

KNOLL, Michael S. Reconsidering International Tax Neutrality. University of Pennsylvania Law School Scholarship Paper 268. Disponível em http://scholarship.law.upenn.edu/faculty scholarship/268/. Acesso em 5.11.2016.

KORNHAUSER, Marjorie E. The Story of Macomber: The continuing legacy of Realization. CARON, Paul L. Tax Stories: An in-depth look at ten leading federal income tax cases. New York: Foundation Press, 2003.

The Origins of Capital Gains Taxation: What's Law Got to Do with It. CARON, Paul L. BURKE, Karen C. McCOUCH, Grayson M.P. Federal Income Tax Anthology. Ohio: Anderson, 1997. KÖRTING, Gustav. Etymologisches Wörterbuch der französischen Sprache. [s.1]: Paderborn, F. Schöningh, 1908.

KPMG. Taxation of Cross-Border Mergers and Acquisitions: Individual Country Reports. 2016. Disponível em https://home.kpmg.com/xx/en/home/insights/2016/05/mergers-and-acquisitions-individual-countryreports.html. Acesso em 5.12.2016.

KRAUS, Pedro Guilherme. Modelo de Internacionalização de Empresas Produtoras Exportadoras Brasileiras. Florianópolis: 2000. Tese de Doutorado apresentada à Faculdade de Engenharia da Universidade Federal de Santa Catarina.

LANG, Joachim. The Influence of Tax Principles on the Taxation of Income from Capital. ESSERS, Peter; RIJKERS, Arie (cords.). The Notion of Income from Capital. Amsterdam: IBFD, 2005.

A Tributação das Empresas no Contexto da Concorrência Internacional. Revista Direito Tributário Atual n 25. São Paulo: IBDT/Dialética, 2011.

LANG, Michael; OWENS, Jeffrey. The Role of Tax Treaties in Facilitating Development and Protecting the Tax Base. WU International Taxation Research Paper Series 2014-03. Disponível em http://papers.ssrn.com/sol3/papers.cfm?abstract_id=2398438. Acesso em 9.10.2016.

O papel dos comentários da OCDE na interpretação dos acordos de bitributação. Revista de Direito Tributário Internacional n 9. São Paulo: Quartier Latin, 2008.

Der Begriff der "Shares" in Art. 13 Abs. 4 OECD-MA. SCHOUERI, Luís Eduardo et. al. (orgs.). Estudos de Direito Tributário em Homenagem ao Prof. Gerd Willi Rothmann. São Paulo: Quartier Latin, 2016.

LAUKKANEN, Antti. Taxation of Investment Derivatives. Doctoral Series 13. Amsterdam: IBFD, 2007.

LAVEZ, Rafael Assef. A Retenção na Fonte na Importação de Serviços Técnicos: Questões não Resolvidas no Caso Copesul. Revista Direito Tributário Atual n 28. São Paulo: IBDT/Dialética, 2012. 
LEE, Chang-Hee. Law and Taxation of Corporate Merger and Division in Korea. Journal of Korean Law. vol. 3, $\mathrm{n}^{\circ}$ 2, 2003. Disponível em http://s-space.snu.ac.kr/bitstream/10371/85064/1/1.\%20Law\%20and\% 20Taxation\%20of\%20Corporate\%20Merger\%20and\%20Division\%20in\%20Korea.pdf. Acesso em 29.7.2016.

LEHNER, Moris. Constitutional, International and European Law. Requeirements for Taxation. German Perspective. SCHOUERI, Luís Eduardo. BIANCO, João Francisco (coords.); CASTRO, Leonardo Freitas de Moraes e; DUARTE FILHO, Paulo César Teixeira (orgs.). Estudos de Direito Tributário em Homenagem ao Prof. Gerd Willi Rothmann. São Paulo: Quartier Latin, 2016.

L'HOTELLERIE-FALLOIS, Domingo J. Jiménez-Valladolid. Reorganization Clauses in Tax Treaties. Amsterdam: IBFD, 2013.

MACHADO, Brandão. Breve Exame Crítico ao Art. 43 do CTN. MARTINS, Ives Gandra da Silva. Estudos sobre o Imposto de Renda: Em Memória de Henry Tilbery. São Paulo: Editora Resenha Tributária, 1994.

MACHADO, Hugo de Brito. O Planejamento Tributário e a Lei Complementar 104. São Paulo: Dialética, 2001.

MACHADO, Raquel Cavalcanti Ramos. Competência Tributária: Entre a rigidez do sistema e a atualização interpretativa. São Paulo: Malheiros, 2014.

MALIK, Gagan; JAIN, Ashish. The Vodafone Tax Journey. Asia-Pacific Tax Bulletin vol. 18. 2012.

MARAFON, Plínio José. Planejamento Tributário - Norma Antielisiva. SCHOUERI, Luís Eduardo. Direito Tributário: Homenagem a Alcides Jorge Costa. São Paulo: Quartier Latin, 2003.

MARKLE, Kevin. A Comparison of the Tax-Motivated Income Shifting of Multinationals in Territorial and Worldwide Countries. 2011. Disponível em http://papers.ssrn.com/sol3/papers.cfm?abstract_id=1764031. Acesso em 9.10.2016.

MARSH, Donald B. The Taxation of Imputed Income. Political Science Quarterly vol 58, n 4. Dec. 1943. MARTINS, Natanael. A Realização da Renda como Pressuposto de sua Tributação. Análise sobre a Perspectiva da Nova Contabilidade e do RTT. MOSQUERA, Roberto Quiroga; LOPES, Alexsandro Broedel (coord.). Controvérsias Jurídico-Contábeis: Aproximações e Distanciamentos. São Paulo: Dialética, 2010.

MATARAZZO, Giancarlo Chamma; ARAÚJO, Joana Franklin de. Caso Copesul: A Tributação de Serviços pelo Imposto de Renda e os Tratados para Evitar a Dupla Tributação. CASTRO, Leonardo F. de Moraes e (org.). Tributação Internacional: Análise de casos. São Paulo: MP Editora, 2010.

MATTOS FILHO, Ary Oswaldo. Notas sobre a Tributação de Ganhos de Capital. São Paulo: 1972. Tese de Doutorado apresentada à Faculdade de Direito da Universidade de São Paulo.

MEIRA, Thaís de Barros; RAMOS, Carolina Cristina Negrão. Caso CCR: Alteração da Jurisprudência do CARF no que Tange à Oponibilidade ao Fisco de Negócios Jurídicos Envolvendo T-Bills e a Comparação com o Caso Vodafone na Índia. CASTRO, Leonardo Freitas de Moraes e (coord.). Planejamento Tributário: Análise de Casos. São Paulo: MP Editora, 2014. 
MERRYMAN, John Henry. Sobre a convergência (e divergência) entre civil law e common law. ASENSI, Felipe Dutra; PAULA, Daniel Giotti de. Tratado de direito constitucional. Rio de Janeiro: Elsevier, 2014. MIWA, Yoshiro; RAMSEYER, J. Mark. The Fable of the Keiretsu. Harvard Law School Discussion Paper No. 316. Disponível em http://www.law.harvard.edu/programs/olin_center/papers/pdf/316.pdf. Acesso em 28.8.2016.

MOREIRA, André Mendes; FONSECA, Fernando Daniel de Moura. Imposto de Renda sobre Ganho de Capital. Necessidade de Realização e Disponibilidade do Acréscimo Patrimonial. Estudo de Caso. Revista Dialética de Direito Tributário n 238. jul/15.

MOREIRA, Clara Gomes. Combate às Práticas Fiscais Danosas e Soberania Fiscal dos Estados. GOMES, Marcus Lívio; SCHOUERI, Luís Eduardo Schoueri (orgs.). A Tributação Internacional na Era PósBEPS: Soluções Globais e Peculiaridades de Países em Desenvolvimento. vol. 1. Rio de Janeiro: Lumen Iuris, 2016.

MOREIRA JUNIOR, Gilberto de Castro. Bitributação Internacional e Elementos de Conexão. São Paulo: Aduaneiras, 2003.

MOSQUERA, Roberto Quiroga. Renda e Proventos de Qualquer Natureza: $O$ imposto e o conceito constitucional. São Paulo: Dialética, 1996.

MUNIZ, Ian de Porto Alegre. Reorganizações societárias. São Paulo, Makron Books, 1996.

Fusões e Aquisições: Aspectos Fiscais e Societários. 2a ed. São Paulo: Quartier Latin, 2011.

MUTÉN, Leif. Treatment of Capital Gains and Losses: A Response. ESSERS, Peter; RIJKERS, Arie (cords.). The Notion of Income from Capital. Amsterdam: IBFD, 2005.

NETO, Luís Flávio. Caso Azadi Bachao: O Desejo de Atrair Capital Estrangeiro e o Consentimento Estatal para Planejamentos Tributários (Treaty Shopping). CASTRO, Leonardo Freitas de Moraes e (coord.). Tributação Internacional: Análise de Casos. São Paulo: MP Editora, 2010.

NETO, Luís Flávio. Teorias do “Abuso” no Planejamento Tributário. 2011. Dissertação de Mestrado apresentada à Faculdade de Direito da Universidade de São Paulo.

NEUMARK, Fritz. Principios de la Imposición. Madrid: IEF, 1974. pp. 316-317.

NEVES, Andrea Nogueira; CALAZANS, Fernanda Junqueira. Remessas de Contraprestação por Serviços Técnicos para o Exterior Vis-à-Vis aos Tratados para Evitar a Dupla Tributação. TÔRRES, Heleno Taveira (coord.). Direito Tributário Internacional Aplicado. vol. III. São Paulo: Quartier Latin, 2005.

NEVES, Márcio Calvet. O imposto de renda na fonte nos pagamentos por prestações de serviços técnicos por residentes no exterior, o Ato Declaratório CST $n^{\circ} 1 / 00$ e as Convenções celebradas pelo Brasil para evitar a dupla tributação da renda. Revista Dialética de Direito Tributário no 58. São Paulo: Dialética, 2000.

NISHIOKA, Alexandre Naoki. Planejamento Fiscal e Elusão Tributária na Constituição e Gestão de Sociedades: Os Limites da Requalificação dos Atos e Negócios Jurídicos pela Administração. 2010. Tese de Doutorado apresentada à Faculdade de Direito da Universidade de São Paulo. 
NOVOA, César García. El Principio de Neutralidad Fiscal y La Financiación de las Sociedades en la Unión Europea. Revista de Direito Tributário 109/110. São Paulo: Malheiros Editores, 2010.

OKUMA, Alessandra. Princípio da Não-Discriminação e a Tributação das Rendas de Não-Residentes no Brasil. TORRES, Heleno Taveira (org.). Direito Tributário Internacional Aplicado. São Paulo: Quartier Latin, 2003.

OLIVEIRA, Phelippe Toledo Pires de. As Convenções Internacionais para Evitar a Dupla Tributação. Revista da AGU vol. 96. 2010.

OLIVEIRA, Ricardo Mariz de. Fundamentos do Imposto de Renda. São Paulo: Quartier Latin, 2008. . Princípios Fundamentais do Imposto de Renda. SCHOUERI, Luís Eduardo (coord.). Direito Tributário: Homenagem a Alcides Jorge Costa. São Paulo: Quartier Latin, 2003.

A Incorporação de Ações no Direito Tributário: Conferência de Bens, Permuta, Dação em Pagamento e Outros Negócios Jurídicos. São Paulo: Quartier Latin, 2014.

OLIVEIRA, Yonne Dolacio de. A tipicidade no Direito Tributário Brasileiro. São Paulo: Saraiva, 1980. OWENS, Richard Norman. Business organizations and combination. New York: Prentice-Hall, 1934.

PATEL, Vispi T.; SHAH, Rajiv. An Analysis of the Supreme Court Judgment in the Vodafone Case. International Transfer Pricing Journal vol. 19. 2012.

PEDREIRA, José Luiz Bulhões. Imposto sobre a Renda: Pessoas Jurídicas. Rio de Janeiro: Justec, 1979.

Finanças e Demonstrações Financeiras da Companhia: Conceitos Fundamentais. Rio de Janeiro: Forense, 1989.

PETERS, Cees. On the Legitimacy of International Tax Law. Doctoral Series vol. 31. The Netherlands: IBFD, 2014.

PIJL, Hans. Os comentários da OCDE como fonte do direito internacional e o papel do poder judiciário. Revista de Direito Tributário Internacional n 4. São Paulo: Quartier Latin, 2006.

PIRES, Manuel. Da dupla tributação jurídica internacional sobre o rendimento. Lisboa: Centro de Estudos Fiscais - Ministério das Finanças, 1984.

PISTONE, Pasquale. Coordinating the Action of Regional and Global Players During the Shift from Bilateralism to Multilateralism in International Tax Law. World Tax Journal $n^{\circ}$ 6. 2014.

POLIZELLI, Victor Borges. O Princípio da Realização da Renda: Reconhecimento de Receitas e Despesas para fins do IRPJ. São Paulo: Quartier Latin / IBDT, 2012.

POPKIN, William D. The Deep Structure of Capital Gains. CARON, Paul L. BURKE, Karen C. McCOUCH, Grayson M.P. Federal Income Tax Anthology. Ohio: Anderson, 1997.

PREBBLE, John. Philosophical and Design Problems that Arise from the Ectopic Nature of Income Tax Law and Their Impact on the Taxation of International Trade and Investment. Chinese Yearbook of International Law and Affairs vol. 13, 1995. Disponível em http://papers.ssrn.com/sol3/papers.cfm?abstract_id=1604906. Acesso em 16.8.2016. 
PRZEPIORKA, Michell. A Tributação de Rendimentos Provenientes de Atos Ilícitos. Revista Direito Tributário Atual n 35. São Paulo: Quartier Latin, 2016.

RÄDLER, Albert J. National and International Tax Consequences of Demergers: General Report. Cahiers de droit fiscal international $\mathrm{n}^{\circ} 79 \mathrm{~b} .1994$.

RAMOS, Luis R. Lara. Mexico's Tax Treaties - Recent Developments. Bulletin for International Taxation. 2010.

REALE, Miguel. Teoria Tridimensional do Direito. 5a ed. São Paulo: Saraiva, 2010.

REQUIÃO, Rubens. Curso de Direito Comercial. vol. 2. 25ª ed. São Paulo: Saraiva, 2007.

REZEK, José Francisco. Direito Internacional Público: Curso Elementar. $11^{\text {a }}$ Ed. São Paulo: Saraiva, 2008.

RICHARDSON, Ivor. The Concept of Income and tax policy. Canterbury Law Review n ${ }^{4}$. 1990.

ROCHA, Paulo Victor Vieira da. A Competência da União para Tributar a Renda, nos termos do Art. 43 do CTN. Revista Direito Tributário Atual no 21. São Paulo: IBDT/Dialética, 2007.

ROCHA, Sergio André. Tributação de Lucros Auferidos no Exterior (Lei n 12.973/14). São Paulo: Dialética, 2014.

Troca Internacional de Informações para fins fiscais. São Paulo: Quartier Latin, 2015.

Interpretação dos Tratados para Evitar a Bitributação da Renda. $2^{a}$ ed. São Paulo:

Quartier Latin, 2013.

O Ato Declaratório $n^{\circ}$ 1/2000 e a ilegalidade da obrigação de retenção do imposto de renda na fonte. Revista Dialética de Direito Tributário no 58. São Paulo: Dialética, 2000.

A Qualificação no Direito Internacional Tributário. Revista de Direito Tributário Internacional $n^{\circ}$ 8. São Paulo: Quartier Latin, 2008.

Questões Fundamentais do Imposto de Renda Após a MP $n^{\circ}$ 627. MOSQUERA, Roberto Quiroga; LOPES, Alexsandro Broedel (coord.). Controvérsias Jurídico-Contábeis: Aproximações e Distanciamentos. vol. 5. São Paulo: Dialética, 2014.

Nova lei tributária deveria estabelecer a neutralidade como princípio. Consultor Jurídico.

27.9.2014. Disponível em http://www.conjur.com.br/2014-set-27/lei-tributaria-deixa-lado-neutralidadeprincipio. Acesso em 1.10.2016.

El Proyecto BEPS de la OCDE y el Derecho Fiscal Internacional en Brasil. Revista Direito Tributário Atual n 35. São Paulo: IBDT/Dialética, 2016.

ROTHMANN, Gerd Willi. O princípio da legalidade tributária. Revista da Faculdade de Direito da


http://www.revistas.usp.br/rfdusp/article/download/66651/69261. Acesso em 16.8.2016. 
Inconstitucionalidade Múltipla na Tributação da Importação de Serviços: Réquiem ou Catarse do Sistema Tributário Nacional? São Paulo: 2010. Tese de Livre-Docência apresentada à Faculdade de Direito da Universidade de São Paulo.

Bitributação internacional. Temas fundamentais do direito tributário atual. Belém: CEJUP, 1983.

Problemas de qualificação na aplicação das convenções contra a bitributação internacional.

Revista Dialética de Direito Tributário nº 76, São Paulo, Dialética, 2002.

Tributação Internacional sem Sujeito Passivo: uma Nova Modalidade do Imposto de Renda sobre Ganhos de Capital? ROCHA, Valdir de Oliveira (coord.). Grandes Questões Atuais do Direito Tributário. vol. 10. São Paulo: Dialética, 2006.

Tributação dos Ganhos de Capital nas Relações Internacionais: Sujeito Passivo Fazendário,

Judicial ou Legal?. Revista de Direito Tributário Internacional n 8. São Paulo: Quartier Latin, 2008.

.; PACIELLO, Gaetano. Elisão e Evasão Fiscal. MARTINS, Ives Gandra da Silva (coord.).

Caderno de Pesquisas Tributárias n 13. São Paulo: CEEU / Resenha Tributária, 1988.

RUBINSTEIN, Flávio. Interpretação e Aplicação dos Acordos de Bitributação: O Papel da Boa-fé

Objetiva. Revista de Direito Tributário Internacional no 3. São Paulo: Quartier Latin, 2006.

SACCARDO, Nicola. Art. 24(3) of the OECD Model Convention: The Significance of the Expression 'Taxation on a Permanent Establishment' in Cross-border Reorganizations. Intertax vol. 31. 2003.

SALERNO, John, et. al. Tax treaty with Spain provides for structuring opportunities in Argentina. Latin American Tax Newsalert. 2013. Disponível em https://www.pwc.com/us/en/tax-servicesmultinationals/newsletters/latin-american-tax/assets/pwc-argentina-treaty-with-spain.pdf. $\quad$ Acesso em 13.12.2016.

SANTOS, João Victor Guedes. Teoria da Tributação e Tributação da Renda nos Mercados Financeiro e de Capitais. Série Doutrina Tributária vol. VIII. São Paulo: IBDT / Quartier Latin, 2013.

Direito Tributário e Justaposição: A Contabilidade Societária e os Limites à Neutralidade Fiscal. MOSQUERA, Roberto Quiroga; LOPES, Alexsandro Broedel (coords.). Controvérsias JurídicoContábeis: Aproximações e Distanciamentos. São Paulo: Dialética, 2010.

. Escopo Pessoal dos Tratados: O Conceito de "Liable to Tax” à luz do caso Azadi Bachao.

Revista de Direito Tributário Internacional $n^{\circ}$ 13. vol. 5. dez/2009.

SANTOS, Ramon Tomazela. O Princípio da Universalidade na Tributação da Renda: Análise Acerca da Possibilidade de Atribuição de Tratamento Jurídico-tributário Distinto a Determinados Tipos de Rendimentos Auferidos por Pessoas Físicas. Revista Direito Tributário Atual n ${ }^{\circ} 28$. São Paulo: Quartier Latin, 2016.

SAUVANT, Karl P. SACHS, Lisa E. The Effect of Treaties on Foreign Direct Investment: Bilateral Investment Treaties, Double Taxation Treaties, and Investment Flows. Oxford: oxford University Press, 2009. 
SAX, Emil. Grundlegung der theoretischen Staatswirtschaft. Wien: Alfred Hölder, 1887.

SCHNEIDER, Markus. Recent Developments Concerning the Rules on the Transfer of Business Functions. International Transfer Pricing Journal. 2011.

SCHÖN, Wolfgang. International Accounting Standards: A Starting Point for a Common European Tax Base? European Taxation. vol. 44, $\mathrm{n}^{\circ}$ 10. out/2004. Disponível em http://papers.ssrn.com/sol3/papers.cfm?abstract_id=1603758. Acesso em 17.9.2016.

SCHOUERI, Luís Eduardo; BARBOSA, Mateus Calicchio. A Persona e o Direito: entre a Realidade e a Ficção das Pessoas Jurídicas. Revista Direito Tributário Atual n³ 30. São Paulo: IBDT/Dialética, 2014. O Mito do Lucro Real na Passagem da Disponibilidade Jurídica para a Disponibilidade Econômica. MOSQUERA, Roberto Quiroga; LOPES, Alexsandro Broedel (coords.). Controvérsias Jurídico-Contábeis: Aproximações e Distanciamentos. São Paulo: Dialética, 2010.

Contribuição à História dos Acordos de Bitributação: A Experiência Brasileira. Revista Direito Tributário Atual n 22. São Paulo: IBDT/Dialética, 2008.

Ágio em Reorganizações Societárias: Aspectos Tributários. São Paulo: Dialética, 2012. Direito Tributário. $5^{\text {a }}$ ed. São Paulo: Saraiva, 2015.

; FREITAS, Rodrigo de. Planejamento Tributário e o "Propósito Negocial": Mapeamento de decisões do Conselho de Contribuintes de 2002 a 2008. São Paulo: Quartier Latin, 2010.

Planejamento Fiscal Através de Acordos de Bitributação: Treaty Shopping. São Paulo: Editora Revista dos Tribunais, 1995.

O Projeto BEPS: Ainda uma Estratégia Militar. GOMES, Marcus Lívio; SCHOUERI, Luís Eduardo Schoueri (orgs.). A Tributação Internacional na Era Pós-BEPS: Soluções Globais e Peculiaridades de Países em Desenvolvimento. vol. 1. Rio de Janeiro: Lumen Iuris, 2016.

SCHOUERI, Pedro. Comparison of the OECD and ILADT Model Conventions. Bulletin for International Taxation $\mathrm{n}^{\circ}$ 9. 2014. Disponível em http://online.ibfd.org/collections/bit/html/bit_2014_09_02_2.html. Acesso em 31.7.2016.

SELIGMAN, Edwin R.A. The Income Tax: A Study of the History, Theory and Practice of the Income Taxation at Home and Abroad. New York: The MacMillan Company, 1911.

Principles of Economics: With Special Reference to American Conditions. New York: Longmans, Green, and Co., 1905.

SILVA, Virgílio Afonso da. Princípios e regras: mitos e equívocos acerca de uma distinção. Revista Latino-americana de Estudos Constitucionais. Belo Horizonte, 2003.

SILVEIRA, Ricardo Maitto. O Princípio da Realização da Renda no Direito Brasileiro. Revista Direito Tributário Atual no 21. São Paulo: Dialética / IBDT, 2007. 
O Escopo Pessoal dos Acordos Internacionais contra a Bitributação: Regimes Especiais, Conflitos de Qualificação e Casos Triangulares. Série Doutrina Tributária vol. XIX. São Paulo: IBDT / Quartier Latin, 2016.

SIMIONATO, Frederico Augusto Monte. A Disciplina da Reorganização da Empresa em Crise Econômica no Projeto de Lei Concursal. Revista de Direito Mercantil, Industrial, Econômico e Financeiro n ${ }^{\circ} 11$. São Paulo: Malheiros, 1998.

SIMONE, Diego Caldas Rivas de. Segurança Jurídica e Tributação: Da Certeza do Direito à Proteção da Confiança Legítima do Contribuinte. São Paulo: Quartier Latin, 2011.

SIMONTACCHI, Stefano. Taxation of Capital Gains under the OECD Model Convention: With Special Regard to Immovable Property. Alphen aan den Rijn: Kluwer Law International, 2007.

SINGH, Harbir. Challenges in Researching Corporate Restructuring. Journal of Management Studies $n^{\circ}$ 30. 1993.

SMITH, Adam. A Riqueza das Nações: Investigações sobre sua Natureza e suas Causas. São Paulo: Nova Cultura, 1996.

STADLER, Rainer; BINDL, Elmar. The German Economic Growth Acceleration Act: Main Changes and Opportunities for Taxpayers. European Taxation. 2010.

SUSARLA, Kamesh; RAVISANKAR, Ramesh. Beyond Vodafone - The Ripple Effect. Asia-Pacific Tax Bulletin vol. 22. 2016.

SUTTER, Franz Phillip; ZEHETNER, Ulf (eds.). Triangular Tax Cases. Wien: Linde, 2004.

SZTAJN, Rachel. Fusão, incorporação e cisão de sociedades: formas de reorganização da estrutura societária na Lei n.9457/97. BULGARELLI, Waldírio; et. al. Reforma da Lei das Sociedades por Ações. São Paulo: Pioneira, 1998.

Reorganização societária e concorrência. Revista de Direito Mercantil, Industrial, Econômico e Financeiro. v. 46, n 148. São Paulo: Malheiros, 2007.

TAKANO, Caio Augusto. Erosão da Base Tributável e a Transferência de Resultados: O Caminho para o Multilateralismo e as Novas Perspectivas à Soberania Fiscal. Revista Direito Tributário Atual $n^{\circ} 32$. São Paulo: IBDT/Dialética, 2014.

TAKENOUSHI, Pedro Issao. Reação do Mercado em Fusões \& Aquisições Cross-Border de Firmas Brasileiras. São Paulo: 2012. Dissertação de Mestrado apresentada à Pontifícia Universidade Católica de São Paulo.

THURONYI, Victor. The Concept of Income. CARON, Paul L. BURKE, Karen C. McCOUCH, Grayson M.P. Federal Income Tax Anthology. Ohio: Anderson, 1997.

TILBERY, Henry. A Tributação dos Ganhos de Capital. São Paulo: Resenha Tributária/IBDT, 1977.

TIPKE, Klaus; LANG, Joachim. Direito Tributário (Steuerrecht). Tradução da $18^{a}$ edição alemã, totalmente refeita, a cargo de Elisete Antoniuk. Vol. III. Porto Alegre: Antonio Fabris Editor, 2014. 
TORRES, Heleno Taveira. Direito Tributário Internacional: Planejamento Tributário e Operações Transnacionais. $2^{\mathrm{a}}$ ed. São Paulo: Revista dos Tribunais, 2001.

Pluritributação Internacional sobre as Rendas de Empresas. São Paulo: RT, 1997.

Direito Constitucional Tributário e Segurança Jurídica: Metódica da Segurança Jurídica do Sistema Constitucional Tributário. São Paulo: Editora Revista dos Tribunais, 2011.

Limites do Planejamento Tributário e a Norma Brasileira Anti-Simulação (LC 104/01). ROCHA, Valdir de Oliveira. (Coord) Grandes Questões Atuais do Direito Tributário. São Paulo: Dialética, 2001.

Planejamento Tributário Internacional. TORRES, Heleno Taveira (Coord) Direito Tributário Internacional Aplicado. vol. 3. São Paulo: Quartier Latin, 2005.

Tipologia da dupla (múltipla) tributação internacional de rendas de empresas: "dupla tributação jurídica internacional" e "dupla tributação econômica internacional”, o fim de um paradigma. Revista Trimestral de Jurisprudência dos Estados vol. 133. Fev. 1995.

Capital Estrangeiro e o Princípio da Não Discriminação Tributaria no Direito Interno e nas Convenções Internacionais. Revista Dialética de Direito Tributário nº 87. São Paulo: Dialética, 2002.

TORRES, Ricardo Lobo. Tratado de Direito Constitucional Financeiro e Tributário: Valores $e$ princípios constitucionais tributários. Rio de Janeiro: Renovar, 2005.

TRIVOLI, Alfonso. A tentative application of the anti-avoidance clause affecting mergers and acquisitions - as recently introduced in the Italian tax system by Article 10 of Law No. 408 of 29 December 1990. Intertax $n^{\circ} 2.1992$.

UCKMAR, Victor, et. al. Manual de Direito Tributário Internacional. São Paulo: Dialética, 2012.

URBAN, Tatiana Proença. O Processo de Internacionalização de uma Multinacional Brasileira. São Paulo: 2006. Dissertação de Mestrado apresentada à Faculdade de Economia, Administração e Contabilidade da Universidade de São Paulo.

VALPY, Francis Edward Jackson. An Etymological Dictionary of the Latin Language. London: A. J. Valpy, 1828.

VAN DEN BROEK, Harm. Cross Border Mergers Within the EU: Proposals to Remove the Remaining Tax Obstacles. Alphen aan den Rijn: Kluwer Law International, 2011.

VAN GERVEN, Dirk. Cross-Border Mergers in Europe. 2 vols. New York: Cambridge University Press, 2010.

VANISTENDAEL, Frans. Taxation of Corporate Reorganizations. THURONYI, Victor. Tax Law Design and Drafting. vol. 2. Washington, D.C.: International Monetary Fund, 1998.

VAN RAAD, Kees. Cinco Regras Fundamentais para a Aplicação de Tratados para Evitar a DuplaTributação. Revista de Direito Tributário Internacional n ${ }^{\circ}$. São Paulo: Quartier Latin, 2005. 
Escopo Geográfico das Regras de Distribuição da Convenção Modelo da OCDE. Revista

Direito Tributário Atual n 22. São Paulo: IBDT/Dialética, 2008.

Não-Discriminação na Tributação de Operações Transnacionais: Escopo e Questões

Conceituais. Revista de Direito Tributário Atual n 19. São Paulo: IBDT/Dialética, 2005.

VAZ, Janaína Campos Mesquita. Recuperação Judicial de Empresas: Atuação do Juiz. São Paulo: 2015.

Dissertação de Mestrado apresentada à Faculdade de Direito da Universidade de São Paulo.

VERÇOSA, Haroldo Malheiros Duclerc. Curso de Direito Comercial. vol. 3. São Paulo: Malheiros Editores, 2008.

; BARROS, Zanon de Paula. A recepção do drop down no direito brasileiro. Revista de direito mercantil-industrial, econômico e financeiro. v. 41, n. 125. São Paulo: Malheiros, 2002.

VOGEL, Klaus. Klaus Vogel On Double Taxation Conventions. $4^{a}$ ed. The Netherlands: Wolters Kluwer, 2015.

Taxation of Cross-border Income, Harmonization, and Tax Neutrality Under European

Community Law: An Institutional Approach. $2^{\text {a }}$ ed. The Netherlands: Kluwer, 1994.

Worldwide vs. Source Taxation of Income: A review and re-evaluation of arguments. Intertax vol. 16. 1988.

Harmonia Decisória e Problemática da Qualificação nos Acordos de Bitributação. SCHOUERI, Luís Fernando; ZILVETI, Fernando Aurélio (coords). Direito Tributário: Estudos em Homenagem a Brandão Machado. São Paulo: Dialética, 1998.

WARDZYNSKI, Adrian. The Limitation on Benefits Article in the OECD Model: Closing Abusive (Undesired) Conduit Gateways. Bulletin for International Taxation, v. 68, n. 9. Amsterdam: IBFD, 2014 WATANABE, Tetsuya. Tax-Free Treatment for Corporate Reorganizations in Japan. University of

California, Berkeley. 2009 Sho Sato Conference on Tax Law. Disponível em https://www.law.berkeley.edu/files/sho_sato_tax_conf_web_paper--watanabe.pdf. Acesso em 30.7.2016.

WEISBACH, David A. The Use of Neutralities in International Tax Policy. Coase-Sandor Institute for Law \& $\quad$ Economics Working $\quad$ Paper $\quad$ No. $\quad 697, \quad 2014$ http://chicagounbound.uchicago.edu/law_and_economics/714/. Acesso em 5.11.2016.

WESTON, John Fred. et. al. Takeovers, Restructuring, and Corporate Governance. $4^{\mathrm{a}}$ ed. New Jersey: Pearson Prentice Hall, 2004.

WHATLEY, Edwin T., et. al. Taxation Aspects of Mergers and Acquisitions. Asia-Pacific Tax Bulletin. Set/Oct 2007.

WHEELER, Joanna. The Missing Keystone of Income Tax Treaties. Doctoral Series vol. 23. The Netherlands: IBFD, 2012.

XAVIER, Alberto. Os princípios da legalidade e da tipicidade da tributação. São Paulo: RT, 1978. Tipicidade da Tributação, Simulação e Norma Antielisiva. São Paulo: Dialética, 2001. 
Direito Tributário Internacional do Brasil. $8^{\mathrm{a}}$ ed. rev. e atual. Rio de Janeiro: Forense, 2015.

Incorporação de Ações: Natureza Jurídica e Regime Tributário. CASTRO, Rodrigo R. Monteiro de; ARAGÃO, Leandro Santos e. Sociedade Anônima: 30 anos da Lei 6.404/76. São Paulo: Quartier Latin, 2007.

XUEREB, Simon. Addressing the Tax Consequences of UCITS IV Cross-Border Mergers in Europe: Extending the Merger Directive as a Solution? - Part 1. European Taxation. 2012.

YAMASHITA, Douglas. Elisão e Evasão de Tributos: Planejamento Tributário - Limites à Luz do Abuso do Direito e da Fraude à Lei. São Paulo: Lex, 2005.

YÁÑEZ, Felipe; BÁEZ, Andréz. La transferencia indirecta de sociedades residentes. VII Encontro do Observatório Interamericano de Tributação Internacional. São Paulo, 2016. Apresentação disponível em http://oiti.uexternado.edu.co/wp-content/uploads/2016/11/Transferencia-indirecta-Baez.pdf. $\quad$ Acesso em 5.12.2016.

ZILVETI, Fernando. O Princípio da Realização da Renda. SCHOUERI, Luís Eduardo (coord.). Direito Tributário: Homenagem a Alcides Jorge Costa. São Paulo: Quartier Latin, 2003.

Variações sobre o Princípio da Neutralidade no Direito Tributário Internacional. Revista Direito Tributário Atual n 19. São Paulo: IBDT/Dialética, 2005. 